\title{
A Holistic Review of Public-Private Partnership Literature Published between 2008 and 2018
}

\author{
Liang Ma, ${ }^{1}$ Junning Li, ${ }^{1}$ Ruoyu Jin $\mathbb{D D}^{2}{ }^{2}$ and Yongjian Ke $\mathbb{D}^{3}$ \\ ${ }^{1}$ School of Management, Shanghai University, Shanghai 200444, China \\ ${ }^{2}$ Built Environment and Civil Engineering, University of Brighton, Brighton BN2 6NF, UK \\ ${ }^{3}$ School of Built Environment, University of Technology Sydney, Ultimo, NSW, Australia \\ Correspondence should be addressed to Ruoyu Jin; r.jin@brighton.ac.uk
}

Received 16 May 2019; Accepted 19 August 2019; Published 5 September 2019

Guest Editor: Jingfeng Yuan

Copyright (c) 2019 Liang Ma et al. This is an open access article distributed under the Creative Commons Attribution License, which permits unrestricted use, distribution, and reproduction in any medium, provided the original work is properly cited.

\begin{abstract}
Adopting a holistic approach in the review of the public-private partnership (PPP) literature published since 2008 by incorporating scientometric analysis and further systematic analysis, this study aims to provide the big picture of the state-of-the-art research in PPP by addressing major issues and suggesting research trends in PPP. Following a three-step research methodology, this study started from a bibliometric analysis with science mapping to provide the state-of-the-art information on PPP research keywords, scholars, journal articles, institutions, and countries. A further systematic review was also conducted to identify future research directions of PPP in project management. The review of the existing literature in PPP revealed that there had been insufficient systematic approach in summarizing the research topics and proposing new research trends in PPP-related project management. It was further indicated that sustainability and innovation in PPP could be further studied, such as integrating building information modeling with PPP. Factors related to barriers in PPP implementation would continue growing. Future research directions in PPP were also proposed following the systematic review, for example, comparative studies of PPP practice between developing and developed countries. The current study provides a comprehensive approach by integrating bibliometric analysis, science mapping, and qualitative analysis in the latest PPP research. It reveals the contemporary research themes in PPP and provides directions for near-future directions of PPP research in project management.
\end{abstract}

\section{Introduction}

Public-private partnership (PPP) refers to the procurement approach where the project is executed with a broader span of contractual relationships between the public and private sectors to provide an asset and/or a service [1]. It is a procurement model to deliver public infrastructure and/or service crossing various sectors including transportation, water treatment, energy, environment, health, and education [2-5]. PPP is believed to provide benefits to the public sector, private sector, and consumers by involving the participation of the government and the private financing initiatives [4]. However, conflicting opinions exist considering the negotiation efficiency, service quality, and accountability within PPPs [6]. PPP-based research has aroused wide interests in recent decades $[6,7]$. Both developing and developed countries have actively been inviting private sectors to be involved in constructing infrastructure projects $[8,9]$.

Although PPP is still at the initial stages in meeting infrastructure development needs for many developing countries [10], new scenarios, findings, and designs have been proposed, adopted, or explored in the PPP field [11]. Case studies of PPP projects have widely been adopted crossing industries leading to new topics and paved the way forward for PPP research [6], including developing PPPrelated frameworks [12], project financing [13], critical success factors (CSFs) [14], concession-related issues [15], and risk allocation and management [16]. Despite of these multiple PPP studies conducted, there has been insufficient attention on outlining the framework and development trends of PPP research [6]. Although certain effort has been paid to explore the research trends in PPP through content 
analysis of renowned construction journals, such as studies conducted by Al-Sharif and Kaka [17] and Ke et al. [18], Song et al. [6] argued that these studies had relied on subjective judgements which might be unreliable due to the possible misinterpretations and misunderstanding on the part of the researchers.

Literature review is an expedient approach to gain indepth understanding of a research field [19]. Existing reviewbased studies in PPP focused on either a certain industry or a wider scope crossing industries. The reviews of Ke et al. [18] and Tang et al. [7] on PPP projects focused on the construction industry. Similarly, Wang et al.'s [20] review of the PPP literature was restricted to the field of public administration. de Castro e Silva Neto et al. [21] started applying bibliometric analysis into the review of PPP studies crossing multiple project sectors such as transportation, health, and energy. But the study of de Castro e Silva Neto et al. [21] was a statistical summary of the existing literature without a deeper analysis (e.g., research trends in PPP). Song et al. [6] adopted the scientometric analysis of PPP-related research in a wide scope covering subjects of engineering, business and economics, and public administration. Researchers in this study believe that these review-based studies can be extended with a more comprehensive coverage, such as research methodology applied in existing PPP studies, the major research focus areas in the last ten years, and the expectations of research directions for the future work. So far limited reviews have linked PPP within the context of project management across multiple industries or sectors with a holistic approach by combining bibliometric analysis, science mapping, and further qualitative analysis.

Continuing from these previous review-based studies in PPP, this study contributes to the body of knowledge by (1) starting from a bibliometric analysis and science mapping of the existing literature since 2008 focusing on PPP in project management, (2) adopting a systematic review of the selected literature sample to summarize and analyze research methods, countries/regions where the PPP studies were performed, project sectors, and key issues within PPP, and (3) analyzing mainstream research topics and recommending future PPP research directions. This study integrates bibliometric analysis, science mapping, quantitative measurements of productive scholars, institutions, countries in PPP research, and systematic review in a holistic approach.

\section{Methodology}

This study adopted a bibliometric analysis of the PPP-based literature followed by the science mapping defined by Tijssen and van Raan [22] and Cobo et al. [23]. A bibliometric analysis examines the bibliographical material from an objective and quantitative perspective which is useful to organize information in a specific field [24, 25]. A bibliometric analysis, by using keywords, allows the analysis of details in main topics within a domain and relationships at the microlevel [26]. Compared to other literature review techniques, bibliometrics provides more objective and reliable analyses [27]. Science mapping describes and diagnoses research policy purposes and processes immense reservoirs of bibliometric data [22]. It displays the structural and dynamic aspects of a scientific research [23, 28] and represents spatially how disciplines, fields, and individual articles or authors relate to one another [29]. Following several existing studies adopting a comprehensive review workflow [30-32], the overall research steps in this reviewbased study of PPP are described in Figure 1, which consists of bibliometric analysis through literature search, science mapping, and follow-up systematic review.

2.1. Bibliometric Analysis. Keyword search was performed in Scopus, which was identified by Aghaei Chadegani et al. [33] as the literature source with a wider coverage of journals and more recent publications compared to other search engines such as Web of Science. Scopus has also been recommended by other studies $[19,34]$ and [35] within the project management field as the literature source. The literature search was set initially by inputting keywords in Scopus denoted below:

TITLE-ABS-KEY (“public-private partnership” OR “publicprivate partnerships" OR "public private partnership” OR "public private partnerships" OR "Public/private Partnerships").

The scope of the search was limited to those published in recent ten years (i.e., from 2008 to 2018), and only journal articles published in English were included in the first-round search. Sources from conference proceedings were excluded. As suggested in [36], conference papers have been published in large number but little has been gained by including them, given the extra amount of complexity added to the analyses. According to Figure 1, after obtaining all journal articles through keyword search, the second-round refinement of the literature was performed to remove articles that did not fall into the project management field. Project management, as defined by multiple studies [37-40], generally involves the monitoring and control of project performance in terms of cost, time, quality, and risks. Following the second-round refinement, a third-round checking was performed to further remove articles which did not focus on PPP-related research themes. In other words, although PPP or relevant terms were mentioned in the article, they were not the focus of the study in project management.

2.2. Science Mapping. The text mining software tool, VOSViewer [41], was adopted to generate the bibliometric map of PPP. In recent years, VOSViewer has been applied in scientometric analysis in the field of project management, such as building information modeling [34], building control [42], and offsite construction [35]. The scientometric review method can also be applied in other research topics [43]. As recommended by Hosseini et al. [35] and Park and Nagy [42], VOSViewer was utilized in this research to (1) import the literature source from Scopus to VOSViewer, (2) compute the frequency and co-occurrence of keywords, (3) extract the citation relationship among articles, authors, publication sources, and institutions, and (4) cluster and visualize keywords, publication sources, and institutions by co-occurrences. 


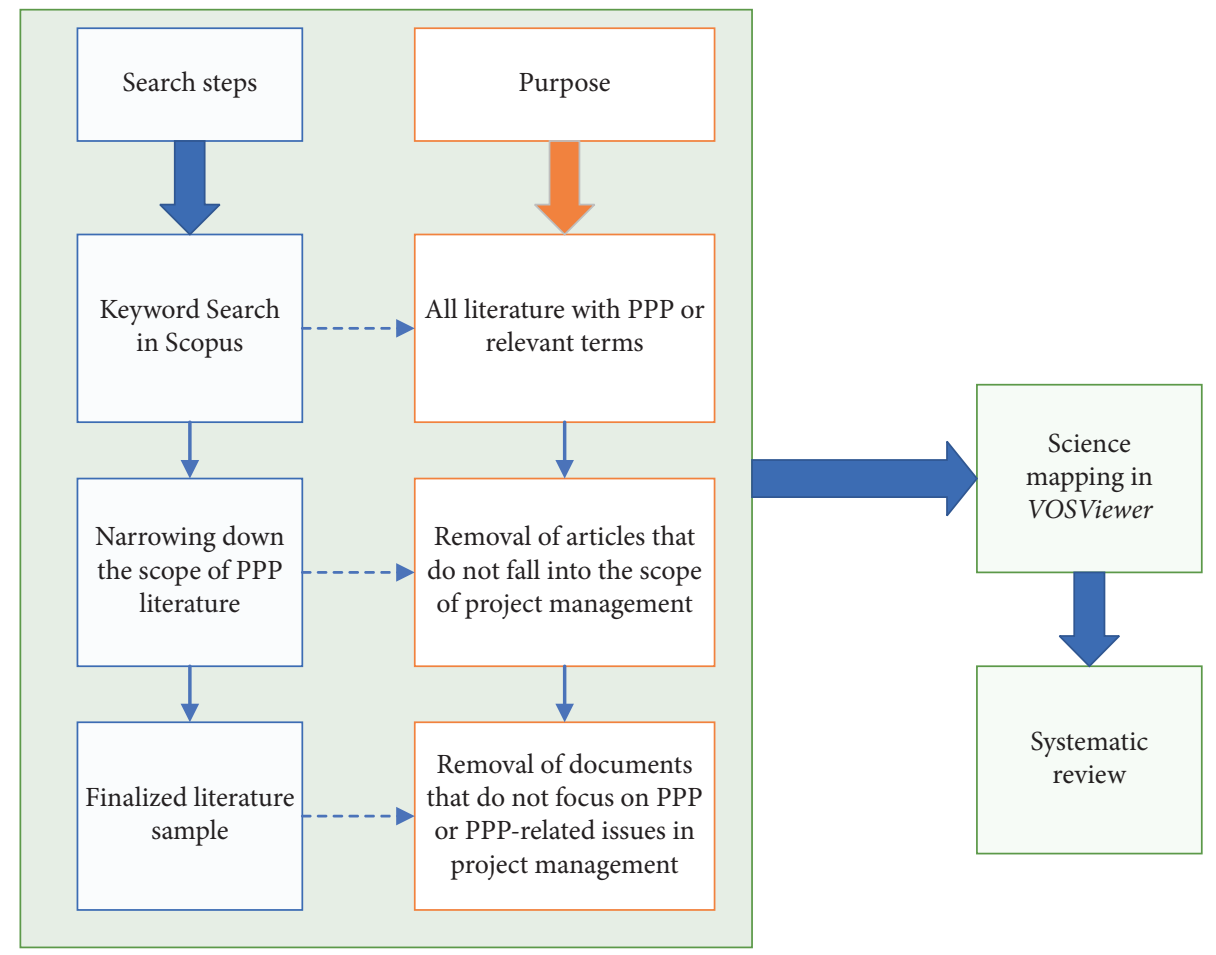

Figure 1: The description of research steps in PPP literature review.

2.3. Systematic Review. Following the bibliometric analysis and science mapping, the systematic review was performed to summarize the current research focus areas in PPP-related project management and to provide suggestions for near-future research trends in PPP themes. Following the suggestions of Tang et al. [7] and de Castro e Silva Neto et al. [21], this study categorized and summarized key issues (e.g., contract performance, financing, and concession) within the refined PPP literature aiming to generate new insights into state-of-the-art research focuses. Besides, project sectors [21] and regions/countries of PPP studies [6] were also categorized and summarized together with methodologies adopted in the literature sample.

\section{Results and Discussion}

By performing the literature search in Scopus, originally 2,340 journal articles published from 2008 to 2018 were found. The majority of the literature in this sample was published from 2008 to 2018 and was hence considered a ten-year span. Reading through the abstract of these selected journal articles, those with PPP in the abstract or keywords but falling out of the scope of project management were excluded to narrow down the search scope. For example, Vasmant's [44] study in the biomedical field, though with PPP-relevant terminology in the abstract and keyword list, did not fall into the category of PPP in project management. Also, those with PPP in the abstract or keyword list but not focusing on PPP-related study were also further excluded. For example, Whyte and Lobo's [45] study focused on the application digital technology in a PPP type of infrastructure project. Although PPP was mentioned in the abstract, it was not the focus of the research. Therefore, journal articles such as Whyte and Lobo [45] was removed from the reference list. Ultimately, totally 1,209 journal articles were selected as the literature sample for this research.

3.1. An Overview of the PPP Literature Sample. The numbers of journal articles published from 2008 to 2018 in the literature sample are summarized in Figure 2.

It can be seen in Figure 2 that generally the number of yearly number of articles has slowly been increasing from 2008 to 2017, with a significant increase in 2018 to reach 353 articles. It could be inferred that the academic research of PPP themes in project management has been remaining or even becoming more popular in recent years. The sources of these articles are visualized in Figure 3 and further described in Table 1.

Setting the minimum number of articles and minimum citations of a source to be 10 and 10, respectively in VOSViewer, totally 14 sources met the requirements and visualized in Figure 3. It should be noticed that there is not really a standardized quantification for the threshold values of article number and citations [46]. However, following the scientometric analysis guide in other project management related studies (e.g., Oraee et al.) $[34,35,46]$ and considering the context of this PPP literature sample, the minimum number of articles and citations were determined. Similar threshold values for keywords, coauthorship, articles, institutions, and countries in PPP-related research could also be determined in the consistent approach following these prior studies. A larger font size in Figure 3 indicates more articles published in the given source. The connection lines 


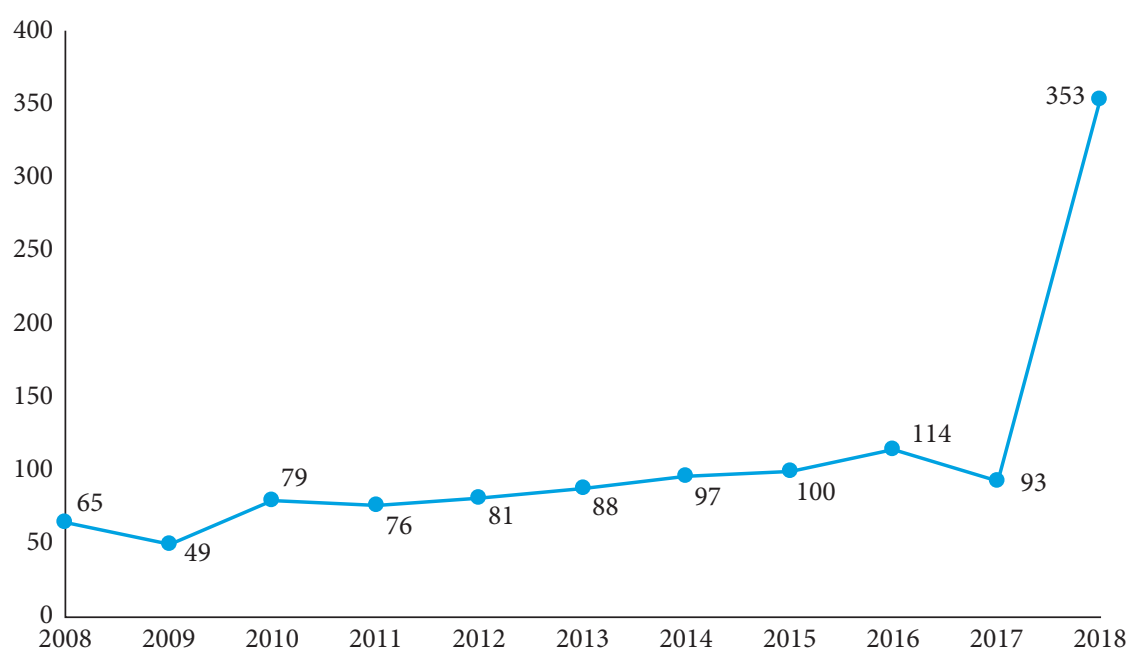

Figure 2: Number of journal articles published from 2008 to 2018.

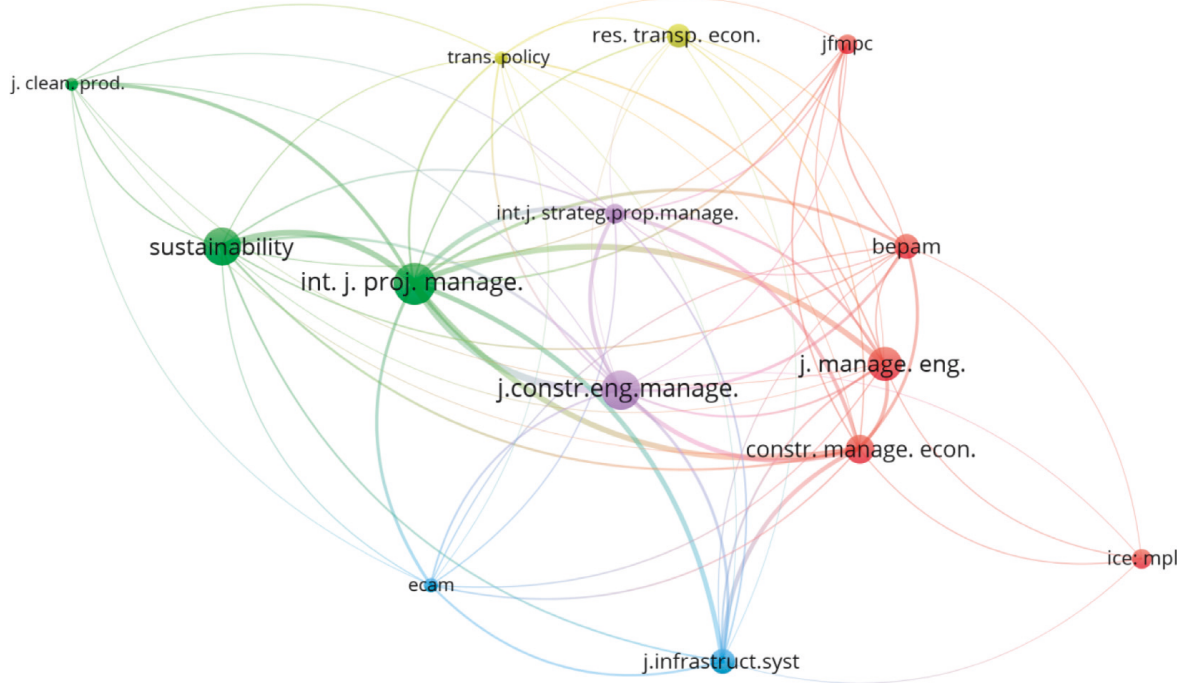

FIGURE 3: Mapping of sources of journal articles within this research. Note: Journal names are presented in Figure 2 using acronyms or abbreviation. The full name of journals can be found in Table 1.

indicate the citation between the pair of given sources. For example, it can be found in Figure 3 that International Journal of Project Management (i.e., Int. J. Proj. Manage.) has a strong cocitation with Journal of Construction Engineering and Management (i.e., J. Constr. Eng. Manage.) in the PPP area. Detailed number of articles, link strength, and citations are listed in Table 1.

Based on the link strength, number of articles published, number of citations, and average citation per article listed in Table 1, the most influential sources in the PPP field would be International Journal of Project Management, followed by Construction Management and Economics, Journal of Construction Engineering and Management, and Journal of Management in Engineering. Other journals indicating the project sectors, including Journal of Infrastructure Systems and Research in Transportation Economics, although not with high total link strength, are also the main sources of the PPP literature considering the number of articles published in these two journals. Among the infrastructure sector, transportation is one of the main sectors that PPP research has focused on. Besides Research in Transportation Economics which contributes to 21 articles in this literature sample, other PPP-related research were found in the transportation sector in sources such as Transportation Research Part A: Policy and Practice, Transportation Research Part D: Transport and Environment, and Transportation Journal.

3.2. Science Mapping. Continuing using VOSViewer as the science mapping tool, the following sientometric analysis was performed in terms of research keywords in the selected PPP literature sample, coauthorship, highly cited journal articles in PPP, and highly productive research organizations and countries in the field of PPP.

3.2.1. Co-Occurrence of Keywords. Keywords represent the core contents of existing studies and describe the areas 
TABLe 1: Analysis of sources in PPP.

\begin{tabular}{|c|c|c|c|c|c|}
\hline Source & $\begin{array}{c}\text { Acronym or abbreviation in } \\
\text { Figure } 3\end{array}$ & $\begin{array}{l}\text { Total link } \\
\text { strength }\end{array}$ & $\begin{array}{c}\text { Number of } \\
\text { articles }\end{array}$ & $\begin{array}{c}\text { Total } \\
\text { citations }\end{array}$ & $\begin{array}{l}\text { Average } \\
\text { citations }\end{array}$ \\
\hline $\begin{array}{l}\text { Built Environment Project and Asset } \\
\text { Management }\end{array}$ & BEPAM & 66 & 22 & 85 & 3.9 \\
\hline $\begin{array}{l}\text { Construction Management and } \\
\text { Economics }\end{array}$ & Constr. Manage. Econ. & 188 & 27 & 522 & 19.3 \\
\hline $\begin{array}{l}\text { Engineering, Construction and } \\
\text { Architectural Management }\end{array}$ & ECAM & 46 & 11 & 119 & 10.8 \\
\hline Proceedings of Institution of Civil & & & & & \\
\hline $\begin{array}{l}\text { Engineers: Management, Procurement } \\
\text { and Law }\end{array}$ & ICE: MPL & 7 & 17 & 32 & 1.9 \\
\hline $\begin{array}{l}\text { International Journal of Project } \\
\text { Management }\end{array}$ & Int. J. Proj. Manage. & 366 & 45 & 887 & 19.7 \\
\hline $\begin{array}{l}\text { International Journal of Strategic Property } \\
\text { Management }\end{array}$ & Int. J. Strateg. Prop. Manage. & 112 & 17 & 127 & 7.5 \\
\hline Journal of Cleaner Production & J. Clean. Prod. & 33 & 10 & 37 & 3.7 \\
\hline Journal of Management in Engineering & J. Manage. Eng. & 113 & 33 & 365 & 11.1 \\
\hline $\begin{array}{l}\text { Journal of Construction Engineering and } \\
\text { Management }\end{array}$ & J. Constr. Eng. Manage. & 193 & 41 & 723 & 17.6 \\
\hline Journal of Infrastructure Systems & J. Infrastruct. Syst & 107 & 23 & 182 & 7.9 \\
\hline $\begin{array}{l}\text { Journal of Financial Management of Property } \\
\text { and Construction }\end{array}$ & JFMPC & 26 & 17 & 103 & 6.1 \\
\hline Research in Transportation Economics & Res. Transp. Econ. & 15 & 21 & 136 & 6.5 \\
\hline Sustainability (Switzerland) & Sustainability & 99 & 39 & 66 & 1.7 \\
\hline Transport Policy & Trans. Policy & 29 & 10 & 90 & 9.0 \\
\hline
\end{tabular}

Total link strength corresponds to Figure 3 and indicates the interrelatedness between the given journal and other peer journals.

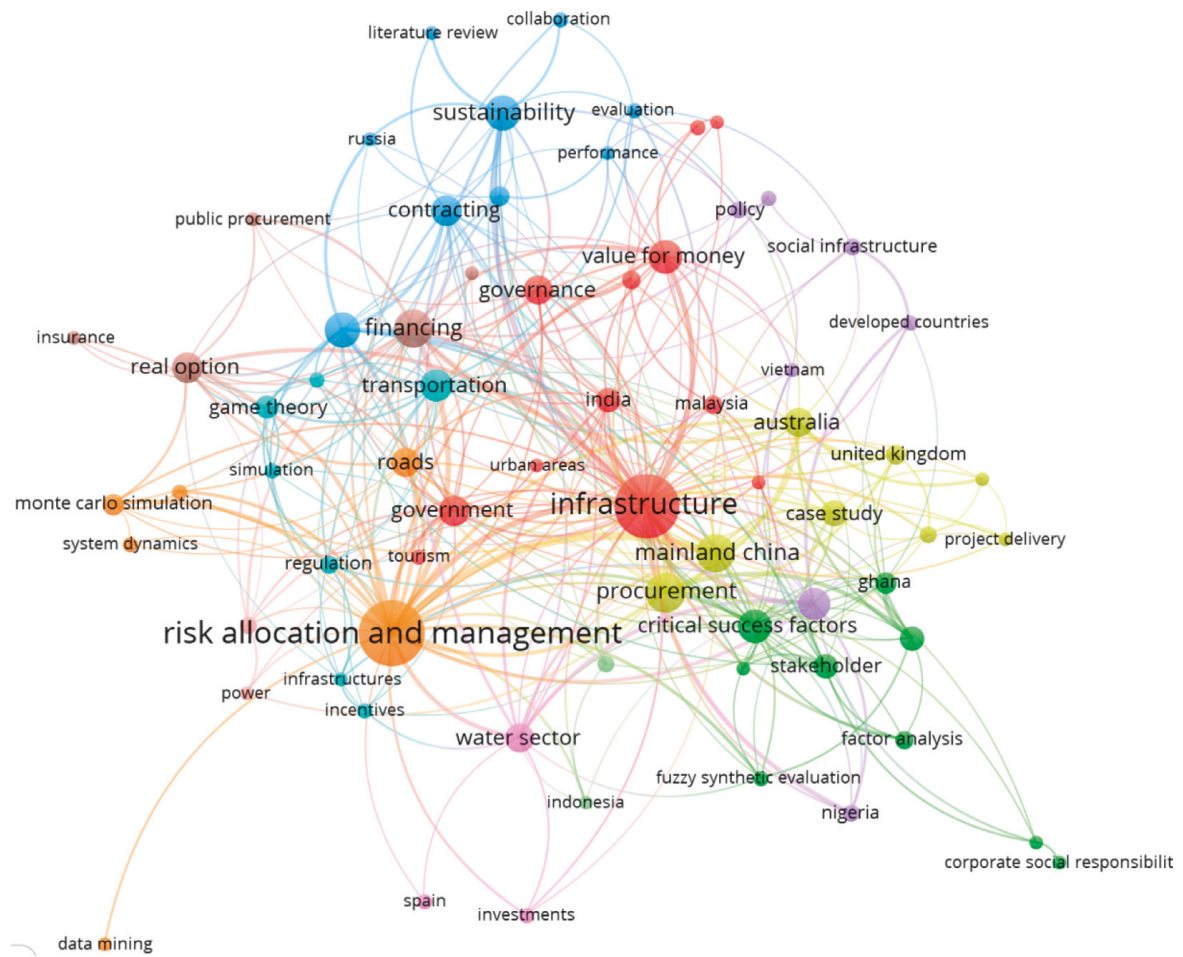

FIGURE 4: Co-occurrence of keywords.

researched within the boundaries of a domain [47]. According to van Eck and Waltman [48], a network of keywords provides the picture of knowledge in terms of patterns, relationships, and intellectual organization of research topics. From totally 2,669 keywords extracted through the literature database, with the minimum number of occurrences set at 5 using Author Keywords, and by removing some generic keywords (e.g., "PPP," "publicprivate partnerships," and "project,"), originally 99 keywords were generated. By further merging keywords with 
TABle 2: Summaries of most frequently studied keywords in PPP.

\begin{tabular}{|c|c|c|c|c|}
\hline Studied keywords & Total link strength & Frequency & Average year published & Average citations \\
\hline Risk Allocation and Management (RAM) & 88 & 132 & 2013 & 12 \\
\hline Infrastructure & 88 & 124 & 2014 & 11 \\
\hline Procurement & 36 & 47 & 2013 & 13 \\
\hline Mainland China & 34 & 43 & 2014 & 20 \\
\hline Financing & 30 & 42 & 2013 & 9 \\
\hline Concession & 26 & 37 & 2014 & 6 \\
\hline Sustainability & 23 & 37 & 2016 & 3 \\
\hline Critical Success Factors & 20 & 32 & 2015 & 13 \\
\hline Value for Money & 20 & 32 & 2013 & 9 \\
\hline Developing Countries & 25 & 30 & 2015 & 4 \\
\hline Transportation & 18 & 29 & 2015 & 5 \\
\hline Government & 19 & 27 & 2015 & 5 \\
\hline Real Option & 19 & 27 & 2014 & 11 \\
\hline Contracting & 15 & 26 & 2015 & 4 \\
\hline Australia & 25 & 25 & 2013 & 11 \\
\hline Roads & 17 & 24 & 2014 & 10 \\
\hline Water Sector & 21 & 24 & 2012 & 7 \\
\hline Governance & 13 & 23 & 2015 & 4 \\
\hline Case Study & 11 & 18 & 2015 & 9 \\
\hline India & 14 & 17 & 2014 & 6 \\
\hline Hong Kong & 15 & 16 & 2013 & 15 \\
\hline Stakeholder & 12 & 16 & 2015 & 10 \\
\hline Game Theory & 9 & 14 & 2016 & 3 \\
\hline Monte Carlo Simulation & 9 & 13 & 2016 & 5 \\
\hline Ghana & 7 & 12 & 2017 & 3 \\
\hline Innovation & 6 & 11 & 2015 & 6 \\
\hline
\end{tabular}

consistent semantic meanings (e.g., "case study" and "case studies") and categorizing keywords (e.g., "risk analysis," "risk management," and "risk assessment" were all categorized into "risk allocation and management"), finally 72 keywords were generated. This corresponding network was created using VOSViewer in Figure 4.

The following can be indicated from the node size and connection lines: (1) Risk allocation and management (RAM) is one of the most frequently studied research topics in PPP projects. Other key research topics in PPP involve procurement, critical success factors (CSF), financing, concession, regulation, contracting, value for money (VFM), and governance. (2) Infrastructure, including roads and water, is the sector that PPP research has frequently focused on. (3) Some widely applied research methods used in PPP-based project management include case study, simulation, data mining, game theory, and fuzzy synthetic evaluation. (4) Besides developed countries (e.g., U.K., Australia, and Spain), PPP has also widely been studied in developing countries such as China, India, Ghana, Malaysia, and Nigeria. (5) The project participants (e.g., government and stakeholder) in both public and private sectors were also one key issue studied. (6) Sustainability and innovation were another two frequently studied issues in PPP research. A more quantitative analysis of these main keywords is summarized in Table 2.

It should be noticed that only part of the most frequently studied keywords from the total sample of 72 are listed in Table 2. Most keywords appear in the literature from 2011 to 2014, indicating that most of them have been in the research community before 2014. Only a few other keywords including "game theory," "Monte Carlo simulation," and "data mining" appear, coming to the research community more recently with the average publication year in 2015. The correlation analysis among total link strength, frequency, and average citation of the totally 72 keywords revealed that the total link strength is highly correlated to the frequency of the keyword, with a Pearson correlation coefficient at 0.991 . However, the average citation of a keyword is not affected by its frequency of being studied in the literature, with a Pearson correlation coefficient at 0.214 and corresponding $p$ value at 0.071 between the average citation and the frequency. This weak relationship between frequency and average citation can be proved in the example of RAM, which has the highest frequency of being studied in the literature. Nevertheless, keywords that receive highest average citations is "Mainland China," followed by Hong Kong, CSF, and "procurement." It can be inferred that research topics related to CSF and procurement tend to have higher impact on the academic community of PPP, although RAM tends to be the most popular research topic.

3.2.2. Coauthorship Analysis. Awareness of the existing scientific collaboration networks in a research field enhances the access to funds, specialties, and expertise, improves productivity, and helps researchers reduce isolation [35]. The science mapping in VOSViewer was also used to identify the most productive scholars and the research collaboration among them. With totally 2,396 authors extracted from the literature sample and 3 articles and 30 citations set as the minimum criteria, totally 72 authors were found meeting the threshold. The coauthorship analysis is visualized in Figure 5. 


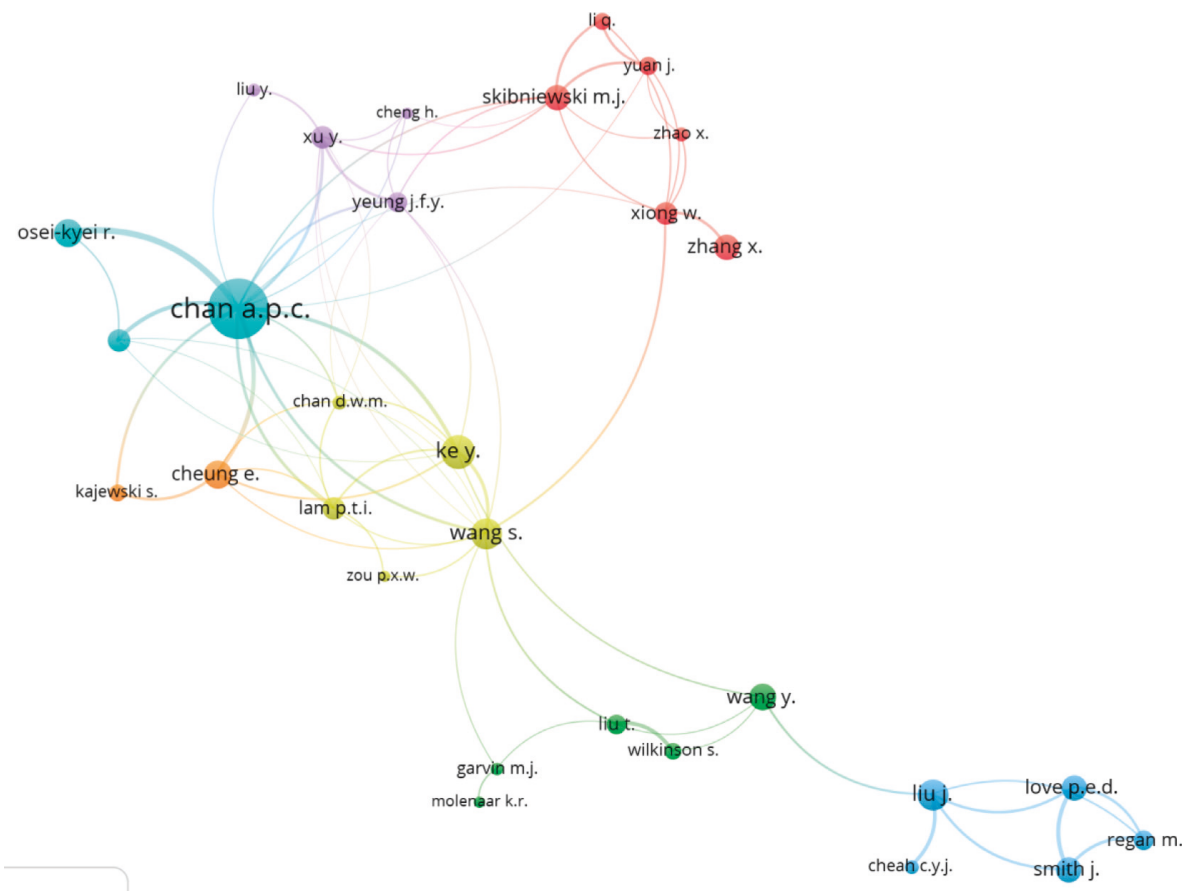

Figure 5: Coauthorship analysis.

It can be indicated from the clusters represented by different colors of nodes, node sizes, and connection lines among scholars shown in Figure 5 that Chan A. P. C., as the most productive author in PPP, has strong collaboration with Ameyaw E. E. and Oseu-Kyer R. Chan A. P. C. has also collaboration with the research network consisting of Ke Y., Wang S., Zou P. X. W., and Lam P. T. I. The other three PPPbased research networks tend to work more closely within their own groups. These three research groups are: (1) network consisting of Love P. E. D., Liu, J., Regan M., Smith J., and Cheah, C. Y. J.; (2) network comprised of Xu Y., Yeung J. F. Y., and Cheng H.; and (3) collaboration among Skiniewski M. J., Yuan J., and Li Q. More detailed description of these main active scholars in PPP field is provided in Table 3.

Totally 30 productive authors are listed in Table 3 . Their average publication years of articles range from 2011 to 2017. Scholars such as Zou P. X. W., Cheng H., and Cheung E. have more of their PPP articles published in earlier years around 2011. In comparison, some scholars are more recently active researchers in the PPP field. For example, OseiKyei R. and Ameyaw E. E. have their work published more recently in 2017 and 2016, respectively. The four major parameters of scholars' PPP research outputs, namely, total link strength, number of articles published, total citations in the academic community, and average citation per article, are analyzed of their internal correlations. Table 4 summarizes the correlation analysis results.

It is found from Table 4 that average citation per article is not related to the total link strength or number of articles published by a scholar. However, it has significant correlation with the total citations. For example, Chan D. W. M., although having only published five articles, has the highest average citation at 58.0 and also high total citations at 290 .
An author who has published more articles will have also a higher impact on the research community measured by total link strength (e.g., Chan A. P. C.).

3.2.3. Citation of Articles. Published PPP-related articles were also mapped based on the citation numbers received. With the minimum number of citations of an article set at 30, totally 64 meet the threshold. These articles receiving most citations are visualized in Figure 6.

It can be found from Figure 6 that these most influential PPP articles in recent ten years were published from 2008 to 2012. Many of these published studies were led by active scholars included in Figure 5 and Table 3, such as Ke Y., Chan A. P. C., Yuan J., and Xu Y. These top 15 articles receiving the highest citations are listed in Table 5.

The number of links listed in Table 5 indicated the interrelatedness of the article to others in the selected sample of highly cited articles. An article with more links indicates that it is more highly cited or citing other articles in the sample. However, it differs from the number of citation in that the latter shows the overall impact of the article to the whole research community. These two parameters are not correlated. For example, the article published by Chan et al. [50] received one of the highest citations in PPP field, although it is with only one link among these articles in the network shown in Figure 6. In contrast, the article published by Jin and Doloi [53] was cited by only 75 times, but it has eight links with other articles shown in Figure 6, indicating its higher degree of interrelatedness with the rest of the articles.

3.2.4. Institutions Productive in PPP Research. Adopting VOSViewer, institutions were analyzed of their 
TABLE 3: List of active scholars in PPP research.

\begin{tabular}{|c|c|c|c|c|c|}
\hline Author & Total link strength & Number of articles & Total citations & Average publication year & Average citation \\
\hline Ameyaw E. E. & 8 & 10 & 59 & 2016 & 5.9 \\
\hline Chan A. P. C. & 52 & 57 & 1069 & 2014 & 18.8 \\
\hline Chan D. W. M. & 5 & 5 & 290 & 2010 & 58.0 \\
\hline Cheah C. Y. J. & 5 & 5 & 43 & 2015 & 8.6 \\
\hline Cheng $\mathrm{H}$. & 2 & 3 & 36 & 2011 & 12.0 \\
\hline Cheung E. & 14 & 15 & 490 & 2011 & 32.7 \\
\hline Garvin M. J. & 2 & 4 & 55 & 2014 & 13.8 \\
\hline Kajewski S. & 6 & 6 & 109 & 2010 & 18.2 \\
\hline Ke Y. & 16 & 20 & 688 & 2012 & 34.4 \\
\hline Lam P. T. I. & 9 & 10 & 367 & 2012 & 36.7 \\
\hline Li Q. & 6 & 6 & 149 & 2012 & 24.8 \\
\hline Liu J. & 14 & 17 & 131 & 2016 & 7.7 \\
\hline Liu T. & 8 & 8 & 52 & 2015 & 6.5 \\
\hline Liu Y. & 2 & 4 & 30 & 2017 & 7.5 \\
\hline Love P. E. D. & 12 & 12 & 104 & 2015 & 8.7 \\
\hline Molenaar K. R. & 1 & 3 & 44 & 2016 & 14.7 \\
\hline Osei-Kyei R. & 15 & 15 & 63 & 2017 & 4.2 \\
\hline Regan M. & 8 & 8 & 110 & 2014 & 13.8 \\
\hline Skibniewski M. J. & 10 & 13 & 193 & 2014 & 14.8 \\
\hline Smith J. & 13 & 13 & 133 & 2015 & 10.2 \\
\hline Wang S. & 15 & 17 & 474 & 2013 & 27.9 \\
\hline Wang Y. & 4 & 14 & 44 & 2016 & 3.1 \\
\hline Wilkinson S. & 6 & 6 & 52 & 2014 & 8.7 \\
\hline Xiong W. & 9 & 10 & 31 & 2016 & 3.1 \\
\hline $\mathrm{Xu} \mathrm{Y.}$ & 10 & 10 & 202 & 2013 & 20.2 \\
\hline Yeung J. F. Y. & 8 & 8 & 254 & 2012 & 31.8 \\
\hline Yuan J. & 7 & 7 & 129 & 2014 & 18.4 \\
\hline Zhang X. & 3 & 13 & 127 & 2014 & 9.8 \\
\hline Zhao X. & 2 & 5 & 70 & 2017 & 14.0 \\
\hline Zou P. X. W. & 2 & 3 & 57 & 2011 & 19.0 \\
\hline
\end{tabular}

TABLE 4: The Pearson correlation analysis among parameters related to authors' impact on PPP research community.

\begin{tabular}{|c|c|c|c|c|}
\hline Correlation analysis & Total link strength & Number of articles & Total citations & Average citation \\
\hline Total link strength & & $r=0.965 ; p=0.000$ & $r=0.835 ; p=0.000$ & $r=0.093 ; p=0.626$ \\
\hline Number of articles & & & $r=0.830 ; p=0.000$ & $r=0.034 ; p=0.857$ \\
\hline Total citations & & & & $r=0.522 ; p=0.003$ \\
\hline
\end{tabular}

$r$ is the Pearson correlation between the selected pair of authors' parameters, and a corresponding $p$ value lower than 0.05 would indicate a significant relationship between the pair of parameters.

contributions to the research outputs of PPP. By setting the minimum number of articles at 3 and minimum citations at 30 as threshold values to screen the totally 2,182 institutions, 14 of them were identified as most research active organizations in PPP.

Figure 7 conveys the information that Hong Kongbased universities, including Hong Kong Polytechnic University (HK Poly U), Hong Kong University of Science and Technology, and Hong Kong Baptist University, are active in PPP research. These three universities have developed their research collaboration with peer institutions in the mainland of China. For example, HK Poly $\mathrm{U}$ has displayed strong collaboration with Tsinghua University, Zhejiang Sci-Tech University, and Southeast University in China. The closer geographic distance could be one factor driving the collaboration for these universities among Taiwan, Hong Kong, and mainland of China (i.e., HK Poly U, National Taiwan University, and
Tsinghua University China). In comparison, Australian universities, including Bond University, Queensland University of Technology, and Curtin University, seem more closely collaborating among themselves by forming their own cluster, although they have developed certain collaboration with peer institutions from other continents, including University of Maryland, Southeast University China, and HK Poly U.

3.2.5. Countries or Regions Active in PPP Research. Similar to the study of institutions productive in PPP research, countries that have been active in PPP research were also analyzed. Setting the minimum number of articles published at 5 , minimum citations received at 30 , totally 32 out of 96 countries met the threshold. These countries where most PPP researchers were based are visualized in Figure 8. 


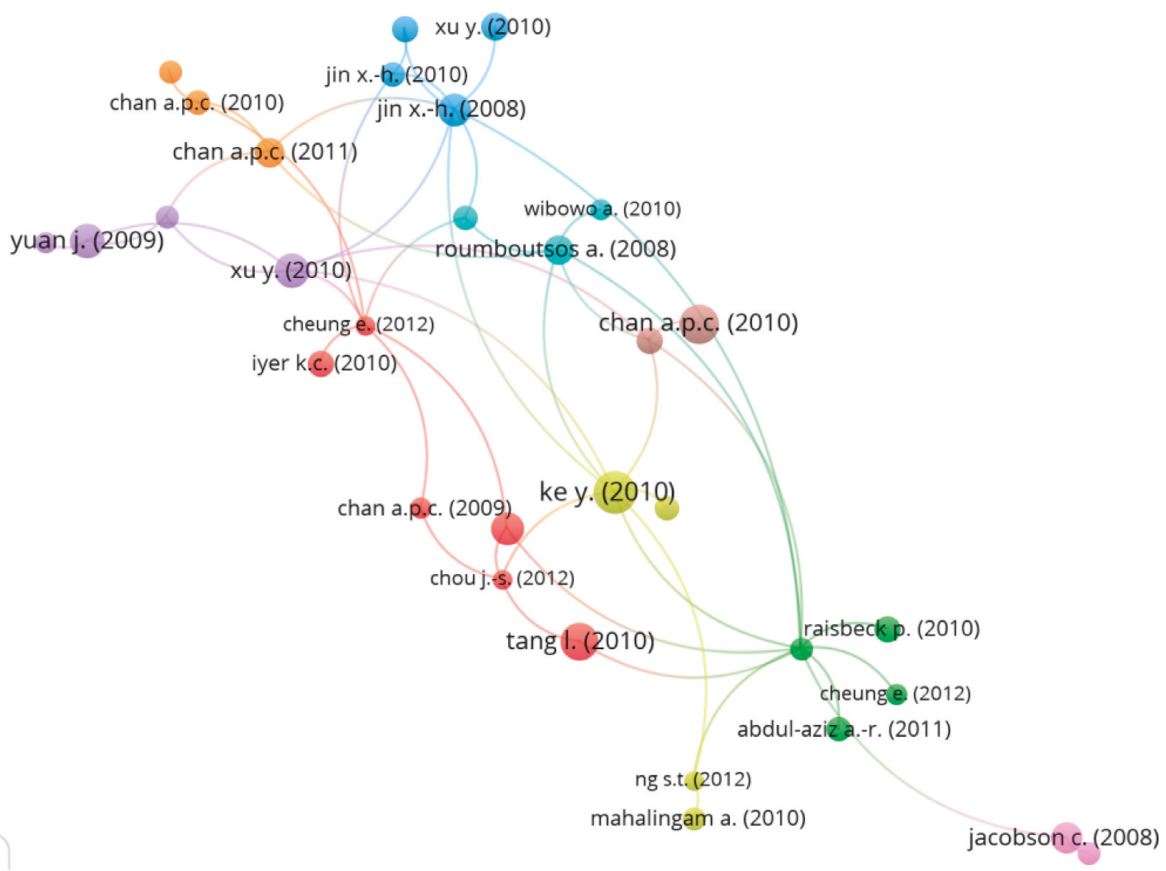

FIGURE 6: Science mapping of PPP articles.

TABLE 5: List of PPP articles with high citations.

Article Title

Number of links Number of citations

Ke et al. [49]

Preferred risk allocation in China's public-private partnership (PPP) projects

Critical success factors for PPPs in infrastructure

Chan et al. [50] developments: Chinese perspective

Tang et al. [7]

A review of studies on public-private partnership projects in the construction industry

Selection of performance objectives and key

Yuan et al. [51]

performance indicators in public-private partnership projects to achieve value for money

$\mathrm{Xu}$ et al. [52]

Jin and Doloi [53]

Ke et al. [18]

Jacobson and Choi [54]

Roumboutsos a Anagnostopoulos [57]

Chan et al. [16]

$\mathrm{Xu}$ et al. [51]

Iyer and Sagheer [57]

Jin and Zhang [58]

Hwang et al. [59]

Raisbeck et al. [60]
Developing a risk assessment model for PPP projects

in China-a fuzzy synthetic evaluation approach

Interpreting risk allocation mechanism in

public-private partnership projects: An empirical

study in a transaction cost economics perspective

Research trends of public-private partnership in construction journals

Success factors: public works and public-private partnerships

Public-private partnership projects in Greece: risk ranking and preferred risk allocation

Empirical study of risk assessment and allocation of public-private partnership projects in China

Developing a fuzzy risk allocation model for PPP projects in China

Hierarchical structuring of PPP risks using interpretative structural modeling

Modeling optimal risk allocation in PPP projects using artificial neural networks

Public-private partnership projects in Singapore:

factors, critical risks and preferred risk allocation from the perspective of contractors

Comparative performance of PPPs and traditional procurement in Australia
8

1

8

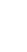

3

6

80

8

3

2

6

4

1

55

1

54

2

5

1 


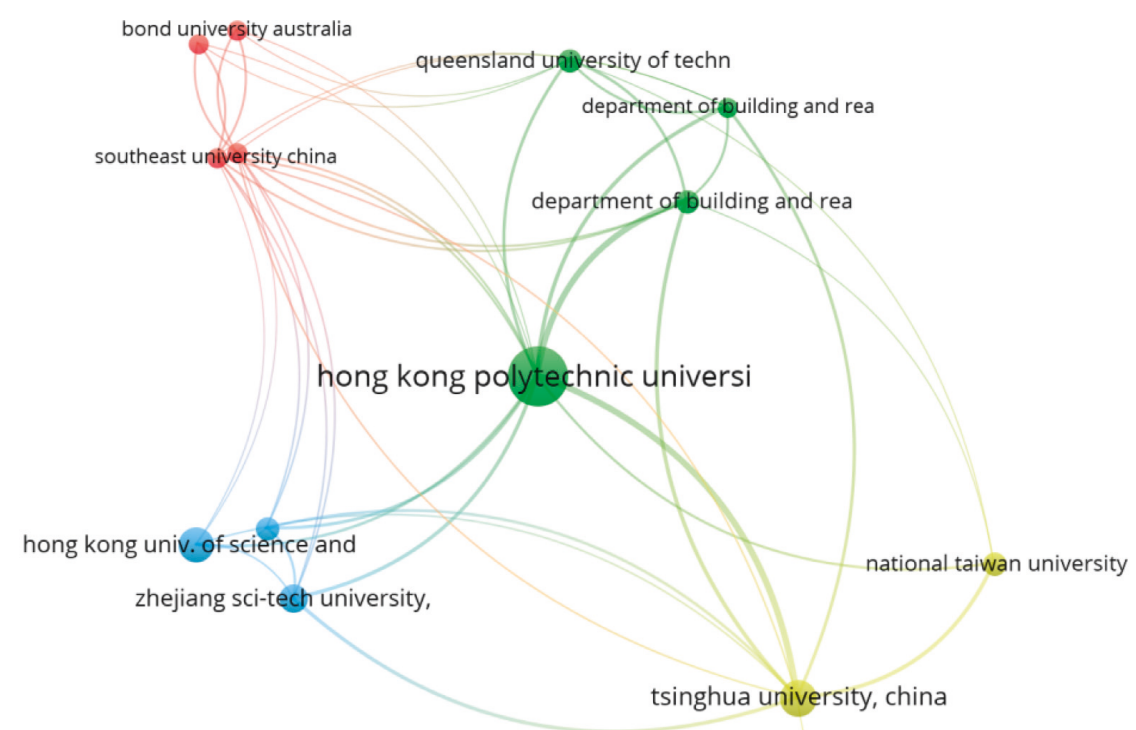

university of toronto

Figure 7: Mapping of organizations active in PPP research.

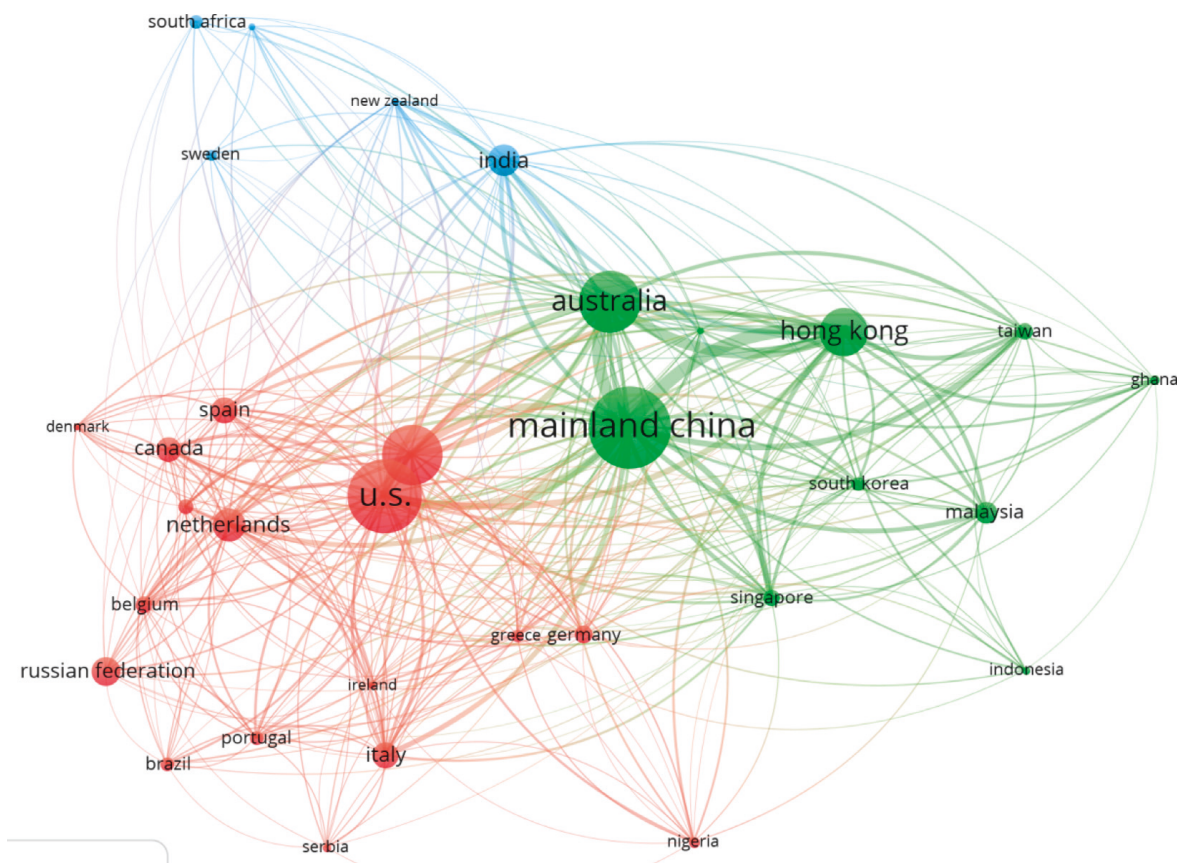

Figure 8: Mapping of countries/regions where PPP researchers were located.

It can be inferred from Figure 8 that PPP researchers have widely distributed crossing developing and developed countries. Developed countries including U.K., U.S., and Australia have largely contributed to the PPP research field. Researchers from developing countries, as indicated by both Figures 4 and 8 , have also been active in PPP research, such as China, India,
Malaysia, and Ghana. These quantitative measurements of countries where PPP researchers are located are summarized in Table 6.

Table 6 shows that China is the country that is most productive in PPP research in terms of total link strength, number of PPP journal articles published, and total citations. 
TABLE 6: Countries or regions where PPP researchers are based.

\begin{tabular}{|c|c|c|c|c|c|}
\hline Country/region & Total link strength & Number of articles & Number of citations & Average publication year & Average citation \\
\hline Mainland China & 1740 & 180 & 1428 & 2016 & 7.9 \\
\hline U.S. & 683 & 159 & 958 & 2015 & 6.0 \\
\hline Australia & 1211 & 126 & 1077 & 2015 & 8.5 \\
\hline UK & 591 & 125 & 895 & 2014 & 7.2 \\
\hline Hong Kong & 1250 & 93 & 1289 & 2014 & 13.9 \\
\hline Netherlands & 276 & 61 & 676 & 2014 & 11.1 \\
\hline India & 218 & 57 & 305 & 2015 & 5.4 \\
\hline Russian Federation & 58 & 51 & 56 & 2016 & 1.1 \\
\hline Italy & 247 & 47 & 269 & 2015 & 5.7 \\
\hline Spain & 161 & 45 & 197 & 2015 & 4.4 \\
\hline Canada & 138 & 44 & 255 & 2015 & 5.8 \\
\hline Malaysia & 216 & 37 & 158 & 2015 & 4.3 \\
\hline Germany & 97 & 30 & 186 & 2013 & 6.2 \\
\hline Belgium & 121 & 27 & 122 & 2016 & 4.5 \\
\hline Singapore & 320 & 26 & 347 & 2013 & 13.3 \\
\hline Taiwan & 274 & 26 & 151 & 2015 & 5.8 \\
\hline France & 107 & 25 & 286 & 2014 & 11.4 \\
\hline South Korea & 120 & 23 & 123 & 2016 & 5.3 \\
\hline Brazil & 55 & 22 & 96 & 2015 & 4.4 \\
\hline Portugal & 109 & 22 & 171 & 2014 & 7.8 \\
\hline
\end{tabular}

Not all 32 countries are listed in Table 6 but the top 20 countries with most PPP articles published are listed.

TABLE 7: Pearson correlation analysis among parameters related to countries/regions' impacts on PPP research.

\begin{tabular}{|c|c|c|c|c|}
\hline Correlation analysis & Total link strength & Number of articles & Number of citations & Average citation \\
\hline $\begin{array}{l}\text { Total link strength } \\
\text { Number of articles } \\
\text { Number of citations }\end{array}$ & & $r=0.871 ; p=0.000$ & $\begin{array}{l}r=0.947 ; p=0.000 \\
r=0.920 ; p=0.000\end{array}$ & $\begin{array}{l}r=0.324 ; p=0.070 \\
r=0.101 ; p=0.582 \\
r=0.404 ; p=0.022\end{array}$ \\
\hline
\end{tabular}

With China as the exception, developed countries or regions are mainstream contributors to PPP research. As can be seen in Table 6, U.S., U.K., Australia, Hong Kong, and Netherlands are also highly productive in PPP studies. The average publication year of articles generally range from 2011 to 2014 among the 32 countries, with the exception that Russia and Belgium are with articles published around 2015. It is inferred that these two countries have more recently become active in PPP research. A correlation analysis among the four parameters (i.e., total link strength, number of articles published, total citations, and average citations) is performed and summarized in Table 7 .

Table 7 demonstrates that these four parameters are generally significantly correlated to each other, except that the number of articles published from a country is not correlated to the average citation per article. Overall, a country's impact to the global PPP research community can be measured by either total link strength, number of published journal articles, total citations, or average citation.

3.3. Systematic Review. Based on the analysis from science mapping, systematic review was performed to the literature sample in terms of the research methodology, project sectors, studied regions/countries, and qualitative analysis of key issues within PPP. It should be noticed that studied region/countries differ from science mapping shown in Figure 8, where the countries refer to where the authors of the published literature were based. The studied countries or regions in this section refer to whether the PPP-related study was performed in the context of a certain country or region. An example explaining the difference could be the study of Osei-Kyei and Chan [61]; while the researchers were located in Hong Kong, the studied country included Ghana.

3.3.1. Summary of Research Methods. The 1,209 articles were summarized of their research methods. As indicated by Figure 4, case studies and other modeling methods (e.g., fuzzy synthetic evaluation) were widely been applied in PPP studies. These main research methods listed in Table 8 include case studies, research modeling and framework, questionnaire survey, interview, literature review, and others.

Other methods listed in Table 8 refer to those without specified methods or generally with qualitative analysis. For example, in the study of Brthen and Odeck [62], an overview of various toll road projects was provided followed by discussions on socioeconomic efficiency via public funding. Similar qualitative analysis can be found in PPP studies including Sohail and Maslyukivska [63], Tang and Lo [64], Mahalingam et al. [65], Petersen [66], and Deshpande and Rokade [67]. It can be found from Table 8 that case studies and modeling are the mainstream research methods implemented in PPP research, followed by questionnairebased survey and interview to PPP-related professionals. 
TABLE 8: Summary of research methodologies in the literature sample.

\begin{tabular}{lcc}
\hline Research method & Number of articles & Percentage \\
\hline Case study & 375 & 29.0 \\
Modeling or framework/model development & 398 & 31.0 \\
Questionnaire survey & 113 & 8.7 \\
Interview & 105 & 8.1 \\
Review & 54 & 4.2 \\
Others & 248 & 19.0 \\
\hline
\end{tabular}

The total percentage may be summed up to be over $100 \%$, as some studies may adopt more than one method. The case that the summed percentage may be higher than 100\% also applies to Tables 9 and 10 where the project sectors and key issues in PPP are summarized respectively.

TABLE 9: Summary of project sectors in the PPP literature.

\begin{tabular}{lcc}
\hline Project sectors & Number of articles & Percentage \\
\hline Transportation & 162 & 13.4 \\
Water & 62 & 5.1 \\
Healthcare & 63 & 5.2 \\
Other construction projects & 42 & 3.5 \\
Public housing & 27 & 2.2 \\
Education & 27 & 2.2 \\
Agriculture & 31 & 2.6 \\
Energy & 36 & 3.0 \\
Waste recycling & 15 & 1.2 \\
Information and communication technology & 11 & 1.0 \\
Preventation/postdisaster projects & 6 & 0.5 \\
Tourism & 17 & 1.4 \\
Physical culture and sport & 5 & 0.4 \\
Apparel and textile industry & 1 & 0.1 \\
Prison & 3 & 0.2 \\
Unspecified & 700 \\
\hline
\end{tabular}

Other construction projects include museum and building construction.

Case studies have been chosen as the research methodology due to the exploratory nature of the research, the limited amount of similar previous research, and the intent to develop knowledge on a contemporary phenomenon $[68,69]$. Modeling approach has also widely been applied in PPPinvolved projects to achieve optimized project performance by considering uncertainties and risks during the project delivery process. Examples of modelling approach in PPP projects include Carbonara and Pellegrino [70] where Monte Carlo simulation was employed, Osei-Kyei and Chan [61] who adopted fuzzy synthetic evaluation method, and Roumboutsos et al. [71] who applied the game theoretic model. Previous studies had also focused on establishing, developing, and testing frameworks for PPP projects, such as Shrestha et al.'s [72] work to build the framework to examine risk allocation for PPP water projects in China. Questionnaire survey, interviews, and review are not unique in PPP research but commonly adopted methods in the field of project management.

3.3.2. Project Sectors. Project sectors targeted in the PPP literature sample are summarized in Table 9.

Consistent to the statistical summary performed by de Castro e Silva Neto et al. [21], the majority of PPP studies did not specify the project sectors. As indicated from the science mapping presented in Figure 4, infrastructure was one of the most frequently studied keywords in the PPP literature.
Among the infrastructure projects, transportation was the sector that was most widely studied according to this study and that of de Castro e Silva Neto et al. [21]. Consistently between these two studies, PPP projects were found applied in multiple sectors including health, education, housing, energy, agriculture, and communication. However, unlike the study of de Castro e Silva Neto et al. [21], who found that the health sector was the second most widely studied sector in PPP, this research identified the water sector as the second most frequently studied sector followed by the health sector. This difference could be due to the years and types of the literature selected. This study only chose journal articles published within the recent ten years, and de Castro e Silva Neto et al. [21] used the literature including both journal articles and conference papers published from 1990 to 2014 . It seems that journal articles have been focusing more on infrastructure project sectors, including transportation and water and waste management.

3.3.3. Studied Regions/Countries. The countries or regions where PPP studies were conducted were also summarized. Around $40 \%$ of the selected studies did not specify countries. For the remaining studies falling into the context of certain countries or regions, the frequencies of countries targeted in the literature sample are presented in Figure 9.

It is shown in Figure 9 that China is the country that has been studied most frequently from the selected literature. 


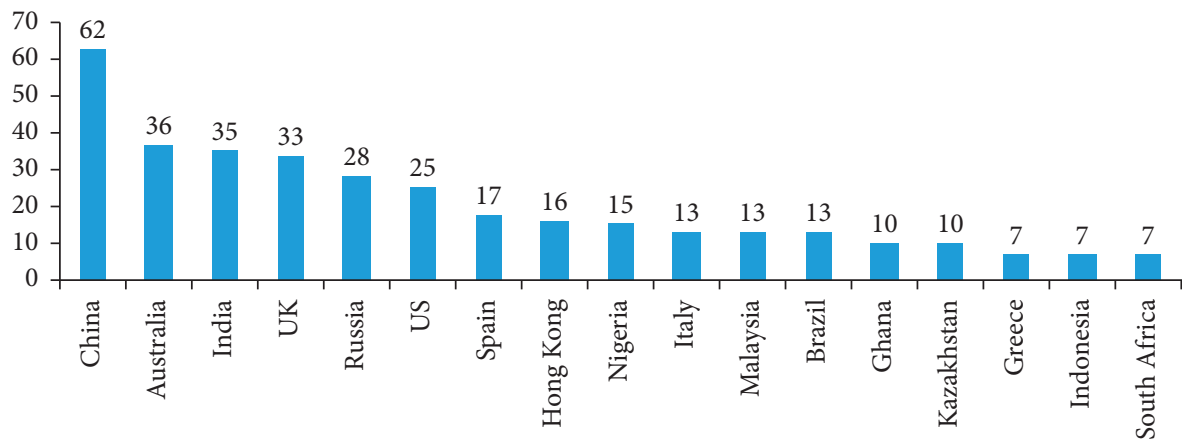

FIgURE 9: Frequencies of countries that have been studied in the literature sample.

TABLE 10: Summary of key issues in the literature sample.

\begin{tabular}{|c|c|c|c|}
\hline Key issues & References & Number of articles & Percentage \\
\hline Project governance (PG) & Guarini and Battisti [75]; Opara and Elloumi [76] & 303 & 22.7 \\
\hline Risk allocation and management (RAM) & {$[77,78]$} & 166 & 12.4 \\
\hline Critical success factors (CSF) & {$[79,80]$} & 120 & 9.0 \\
\hline Performance evaluation (PE) & {$[81,82]$} & 114 & 8.7 \\
\hline PPP models and applications (PMA) & {$[83,84]$} & 188 & 14.1 \\
\hline Economics and financing (EF) & {$[85,86]$} & 91 & 6.8 \\
\hline Contract management $(\mathrm{CM})$ & {$[87,88]$} & 82 & 6.1 \\
\hline Procurement management (PM) & {$[89,90]$} & 45 & 3.4 \\
\hline Legislation and legal issues (LLI) & {$[91,92]$} & 40 & 3.0 \\
\hline Hindering PPP factors (HPF) & {$[93,94]$} & 34 & 2.5 \\
\hline Innovation in PPP (IP) & {$[95,96]$} & 46 & 3.4 \\
\hline Value for money (VFM) & {$[97,98]$} & 26 & 2.0 \\
\hline $\begin{array}{l}\text { Concession-related models, pricing, and periods } \\
\text { (CMPP) }\end{array}$ & {$[99,100]$} & 18 & 1.3 \\
\hline Others & {$[101,102]$} & 62 & 4.6 \\
\hline
\end{tabular}

Figure 8 and Table 6 show that China was the country where scholars had published most PPP-related articles, and Figure 9 further infers that China is also the country that has received the highest attention on $\mathrm{PPP}$ research. This could be due to fact indicated by Zhang et al. [73] and Yang et al. [74] that PPP has been gaining wide implementation and aroused a wide attention from Chinese industry, government, and academia in the last decade.

3.3.4. Qualitative Analysis of Key Issues. Following the studies of Tang et al. [7] and de Castro e Silva Neto et al. [21], as well as key research topics mapped in Figure 4 and Table 2, key issues that have been studied in the literature sample are listed in Table 10.

Each key issue in Table 10 is accompanied with examples of studies from the literature sample. Other key issues studied in the PPP literature include sustainability [103], general summary of PPP project experience [104], overview of PPP research trends [18], application conditions of PPP [105], comparative analysis of PPP [106], and public involvement [107]. Table 10 conveys the information that project governance and risk-related topics have been the most frequently studied issues in the last ten years. Other key issues which were also predicted by Tang et al. [7] that would receive wide concern in PPP research include financing and costs, CSF, risk allocation and management
(RAM), concession-related issues (e.g., concession period), contract management (CM), development of PPP models, and applications. Taking RAM, for example, which is always an active research topic for PPP projects [7], most studies of RAM paid attention to which and to what extent of the risks should be allocated to the relevant stakeholders, i.e., government or private side, and few studies focused on designing or carrying out a realistic risk sharing strategy or reasonable risk sharing ratio between the two parties [73].

\section{Discussion on the Findings}

Based on the three research steps illustrated in Figure 1, this review-based study adopted a bibliometric analysis of journal articles published within the last ten years in the PPP field. Science mapping was applied to explore the research keywords, influential researchers, articles, journal sources, institutions, and countries that had been with high impacts in PPP. The further systematic review of the literature sample provided the statistical summary of the studied countries or regions, research methods, project sectors, and key issues from the selected PPP literature sample.

PPP-based studies in project management have been undergoing a steady increase in the last few years. These few journals, including International Journal of Project Management, Construction Management and Economics, Journal of Construction Engineering and Management, and Journal of 
Management in Engineering, play major roles in PPP research, based on their total link strength, number of articles published in PPP, and citations in the academic community. Research keywords within the PPP literature could be categorized into key issues (e.g., governance), countries (e.g., China), research method (e.g., case study), and project sectors (e.g., transportation). Sustainability and innovation had also been concerned in PPP research. As a sustainable concept, BIM (i.e., building information modeling) was perceived to have significant correlations with PPP projects [108]. Love et al. [109] and Ren and Li [110] proposed utilizing BIM as the digital approach to assist the decisionmaking in VFM within PPP projects. It is indicated that although most PPP studies have focused on the managerial aspects of project management, sustainability and innovation integrated with PPP could be emerging research topics for the future PPP study.

The science mapping of PPP articles, scholars, institutions, and countries indicated that China had generated the most outputs in PPP, in terms of the number of articles published, citations, and total link strength. It was found that these parameters to quantify the impact of a country or an individual scholar on PPP research was generally significantly correlated to each other, meaning that either the total link strength, number of publications, or citation numbers can be used to measure the contribution of the individual scholar, institution, or the country. Chan A. P. C. and his affiliation (i.e., Hong Kong Polytechnic University) are the most productive scholar and institution, respectively, in PPP field during the recent ten years. It is inferred that through the research collaboration with Chan A. P. C., Ameway E. E. and Osei-Kyei R. become rising researchers in more recent years. It can be further indicated that collaboration among scholars and institutions could drive the movement of PPP research in joint efforts.

Although developed countries, such as U.K., U.S., and Australia, have been contributing to more of the existing PPP studies, it is expected that more PPP studies will be carried out in developing countries (e.g., China, India, Ghana, Indonesia, and Nigeria). Some comparative studies between developed countries/regions and their developing counterparts (e.g., [111]) can be expected for the future study in PPP, as political, legislation, and cultural aspects within certain developing countries (e.g., China) would affect the implementation of PPP. When adopting PPP in project management, public and private sectors should consider the regional or the country's context.

Though recently published PPP studies indicated a certain degree of variety within key issues identified in Table 10, a review of these key issues showed that governance, risk management, and CSF represented the most widely studied topics in PPP, these under-represented issues (e.g., hindering factors) could be continued in the future. Hindering factors that cause difficulties or barriers (e.g., uncertainty in decision-making) in PPP implementation would be the ongoing research direction by applying various research methods, such as questionnaire survey and modeling.

\section{Conclusions}

The bibliometric analysis and systematic review of PPP journal articles published revealed that PPP is still steadily growing in the recent ten years. Visualized science mapping and quantitative measurement using parameters (e.g., number of citations) provided the information of popular research keywords, productive PPP scholars, articles with high impacts, and institutions and countries contributing to the PPP research community. The visualized mapping was extended by a follow-up systematic review, based on the summaries of research methods, project sectors, countries that PPP studies focused on, and key issues within PPP research. Major findings from this holistic review-based study can be summarized below:

(1) The most frequently adopted research keywords from the recent ten years' PPP literature could be categorized as key issues (e.g., governance), countries (e.g., Australia), research methods (e.g., case study), industry sectors (e.g., water), and others (e.g., sustainability and innovation).

(2) Sustainability and innovation, such as PPP linked to BIM, could be one of the future research topics.

(3) Hindering factors focusing on barriers and challenges encountered in PPP implementation would be an increasingly studied key issue in PPP research.

(4) Although these more traditional key issues, such as risk management and concession, remain continuing research topics in PPP, a variety of key issues in PPP research can be expected, involving some new emerging topics, for example, the comparative study of PPP adoption between developing and developed countries.

(5) China would be the country where more PPP research are carried out in the near future. Collaboration will continue between China-based researchers and their international peers in PPP.

(6) Case study and modeling/framework are main research methods in PPP research, followed by the traditional questionnaire survey and interview. Qualitative analysis is also being widely applied in PPP studies.

(7) Transportation and water treatment are the two main infrastructure sectors with highest numbers of PPP studies. Linked to sustainability, it could be expected that energy and environment-related projects including waste recycling and diversion projects could receive more attention in PPP research.

Besides the major findings, this study also contributes to the existing knowledge in PPP by providing the following suggestions for future research:

(1) Technological innovation and integration with PPP projects

(2) Modeling or framework established to address hindering factors affecting PPP implementation under certain cultural or legislation context 
(3) Studies tailoring the experience from developed countries to their developing counterparts

(4) Integrating multiple key issues in PPP, for example, how would legislation and legal issues affect the procurement, which would lead to performance evaluation

\section{Conflicts of Interest}

The authors declare that they have no conflicts of interest regarding the publication of this paper.

\section{Acknowledgments}

This study was supported by the Major Project of Shanghai Municipal People's Government Decision-Making Research (Grant number: 2017-A-046) and Shanghai Pujiang Program (Grant number: 16PJ1432400). The authors would also like to acknowledge the Writing Retreat Fund provided by University of Brighton, UK.

\section{References}

[1] L. Tang, Q. Shen, M. Skitmore, and E. W. L. Cheng, "Ranked critical factors in PPP briefings," Journal of Management in Engineering, vol. 29, no. 2, pp. 164-171, 2013.

[2] R. Widdus, "Public-private partnerships for health: their main targets, their diversity, and their future directions," Bulletin of the World Health Organization, vol. 79, no. 8, pp. 713-720, 2001.

[3] N. F. D. Cruz and R. C. Marques, "Delivering local infrastructure through PPPs: evidence from the school sector," Journal of Construction Engineering and Management, vol. 138, no. 12, pp. 1433-1443, 2012.

[4] J. Yuan, M. Guang, X. Wang, Q. Li, and M. J. Skibniewski, "Quantitative SWOT analysis of public housing delivery by public-private partnerships in China based on the perspective of the public sector," Journal of Management in Engineering, vol. 28, no. 4, pp. 407-420, 2012.

[5] J. Song, D. Song, X. Zhang, and Y. Sun, "Risk identification for PPP waste-to-energy incineration projects in China," Energy Policy, vol. 61, pp. 953-962, 2013.

[6] J. Song, H. Zhang, and W. Dong, "A review of emerging trends in global PPP research: analysis and visualization," Scientometrics, vol. 107, no. 3, pp. 1111-1147, 2016.

[7] L. Tang, Q. Shen, and E. W. L. Cheng, "A review of studies on public-private partnership projects in the construction industry," International Journal of Project Management, vol. 28, no. 7, pp. 683-694, 2010.

[8] H. P. Tserng, J. S. Russell, C.-W. Hsu, and C. Lin, "Analyzing the role of national PPP units in promoting PPPs: using new institutional economics and a case study," Journal of Construction Engineering and Management, vol. 138, no. 2, pp. 242-249, 2012.

[9] A. P. C. Chan, R. Osei-Kyei, Y. Hu, and Y. Le, "A fuzzy model for assessing the risk exposure of procuring infrastructure mega-projects through public-private partnership: the case of Hong Kong-Zhuhai-Macao bridge," Frontiers of Engineering Management, vol. 5, no. 1, pp. 64-77, 2018.

[10] A. P. Gurgun and A. Touran, "'Public-private partnership experience in the international arena: case of Turkey," Journal of Management in Engineering, vol. 30, no. 6, Article ID 04014029, 2014.
[11] B. Li, A. Akintoye, P. J. Edwards, and C. Hardcastle, "Critical success factors for PPP/PFI projects in the UK construction industry," Construction Management and Economics, vol. 23, no. 5, pp. 459-471, 2005.

[12] J. Liu, P. Love, B. Carey, J. Smith, and M. Regan, "Ex-ante evaluation of public-private partnerships: macroeconomic analysis," Journal of Infrastructure Systems, vol. 21, no. 2, article 04014038, 2015.

[13] L. Tang and G. Q. Shen, "Finance-related critical success factors for the briefing of PPP projects inconstruction," in Proceedings of the International Conference on Construction and Real Estate Management, pp. 427-437, Karlsruhe, Germany, October 2013.

[14] M. Soomro and X. Q. Zhang, "Evaluation of the functions of public sector partners in transportation public-private partnerships failures," Journal of Management in Engineering, vol. 32, no. 1, article 04015027, 2015.

[15] X. Zhang, "Criteria for selecting the private-sector partner in public-private partnerships," Journal of Construction Engineering and Management, vol. 131, no. 6, pp. 631-644, 2005.

[16] A. P. C. Chan, J. F. Y. Yeung, C. C. P. Yu, S. Q. Wang, and Y. Ke, "Empirical study of risk assessment and allocation of public-private partnership projects in China," Journal of Management in Engineering, vol. 27, no. 3, pp. 136-148, 2011.

[17] F. Al-Sharif and A. Kaka, "PFI/PPP topic coverage in construction journals," in Proceedings of the 20th Annual ARCOM Conference, pp. 711-719, Edinburgh, UK, September 2004.

[18] Y. Ke, S. Wang, A. P. Chan, and E. Cheung, "Research trend of public-private partnership in construction journals," Journal of Construction Engineering and Management, vol. 135, no. 10, pp. 1076-1086, 2009.

[19] Q. He, G. Wang, L. Luo, Q. Shi, J. Xie, and X. Meng, "Mapping the managerial areas of building information modeling (BIM) using scientometric analysis," International Journal of Project Management, vol. 35, no. 4, pp. 670-685, 2017.

[20] H. Wang, W. Xiong, G. Wu, and D. Zhu, "Public-private partnership in public administration discipline: a literature review," Public Management Review, vol. 20, no. 2, pp. 293-316, 2018.

[21] D. de Castro e Silva Neto, C. O. Cruz, F. Rodrigues, and P. Silva, "Bibliometric analysis of PPP and PFI literature: overview of 25 years of research," Journal of Construction Engineering and Management, vol. 142, no. 10, Article ID 06016002, 2016.

[22] R. J. W. Tijssen and A. F. J. van Raan, "Mapping changes in science and technology," Evaluation Review, vol. 18, no. 1, pp. 98-115, 1994.

[23] M. J. Cobo, A. G. López-Herrera, E. Herrera-Viedma, and F. Herrera, "An approach for detecting, quantifying, and visualizing the evolution of a research field: a practical application to the fuzzy sets theory field," Journal of Informetrics, vol. 5, no. 1, pp. 146-166, 2011.

[24] J. M. Merigó, A. M. Gil-Lafuente, and R. R. Yager, "An overview of fuzzy research with bibliometric indicators," Applied Soft Computing, vol. 27, pp. 420-433, 2015.

[25] G. Albort-Morant and D. Ribeiro-Soriano, "A bibliometric analysis of international impact of business incubators," Journal of Business Research, vol. 69, no. 5, pp. 1775-1779, 2016.

[26] G. Chen and L. Xiao, "Selecting publication keywords for domain analysis in bibliometrics: a comparison of three 
methods," Journal of Informetrics, vol. 10, no. 1, pp. 212-223, 2016.

[27] M. Aria and C. Cuccurullo, "Bibliometrix: an R-tool for comprehensive science mapping analysis," Journal of Informetrics, vol. 11, no. 4, pp. 959-975, 2017.

[28] M. J. Cobo, A. G. López-Herrera, E. Herrera-Viedma, and F. Herrera, "Science mapping software tools: review, analysis, and cooperative study among tools," Journal of the American Society for Information Science and Technology, vol. 62, no. 7, pp. 1382-1402, 2011.

[29] H. Small, "Visualizing science by citation mapping," Journal of the American Society for Information Science, vol. 50, no. 9, pp. 799-813, 1999.

[30] Y. Xu, J. Zeng, W. Chen, R. Jin, B. Li, and Z. Pan, "A holistic review of cement composites reinforced with graphene oxide," Construction and Building Materials, vol. 171, pp. 291-302, 2018.

[31] W. Chen, R. Jin, Y. Xu et al., "Adopting recycled aggregates as sustainable construction materials: a review of the scientific literature," Construction and Building Materials, vol. 218, pp. 483-496, 2019.

[32] R. Jin, H. Yuan, and Q. Chen, "Science mapping approach to assisting the review of construction and demolition waste management research published between 2009 and 2018," Resources, Conservation and Recycling, vol. 140, pp. 175-188, 2019.

[33] A. Aghaei Chadegani, H. Salehi, M. M. Md Yunus et al., "A comparison between two main academic literature collections: web of science and scopus databases," Asian Social Science, vol. 9, no. 5, pp. 18-26, 2013.

[34] M. Oraee, M. R. Hosseini, E. Papadonikolaki, R. Palliyaguru, and M. Arashpour, "Collaboration in BIM-based construction networks: a bibliometric-qualitative literature review," International Journal of Project Management, vol. 35, no. 7, pp. 1288-1301, 2017.

[35] M. R. Hosseini, I. Martek, E. K. Zavadskas, A. A. Aibinu, M. Arashpour, and N. Chileshe, "Critical evaluation of offsite construction research: a scientometric analysis," Automation in Construction, vol. 87, pp. 235-247, 2018.

[36] L. Butler and M. S. Visser, "Extending citation analysis to non-source items," Scientometrics, vol. 66, no. 2, pp. 327343, 2006.

[37] A. Abdi, S. Taghipour, and H. Khamooshi, "A model to control environmental performance of project execution process based on greenhouse gas emissions using earned value management," International Journal of Project Management, vol. 36, no. 3, pp. 397-413, 2018.

[38] Y. Li, Y. Lu, J. E. Taylor, and Y. Han, "Bibliographic and comparative analyses to explore emerging classic texts in megaproject management," International Journal of Project Management, vol. 36, no. 2, pp. 342-361, 2018.

[39] P. Sirisomboonsuk, V. C. Gu, R. Q. Cao, and J. R. Burns, "Relationships between project governance and information technology governance and their impact on project performance," International Journal of Project Management, vol. 36, no. 2, pp. 287-300, 2018.

[40] F. Zuo and K. Zhang, "Selection of risk response actions with consideration of secondary risks," International Journal of Project Management, vol. 36, no. 2, pp. 241-254, 2018.

[41] N. J. van Eck and L. Waltman, "Software survey: VOS viewer, a computer program for bibliometric mapping," Scientometrics, vol. 84, no. 2, pp. 523-538, 2010.

[42] J. Y. Park and Z. Nagy, "Comprehensive analysis of the relationship between thermal comfort and building control research-a data-driven literature review," Renewable and Sustainable Energy Reviews, vol. 82, pp. 2664-2679, 2018.

[43] X. Zhao, "A scientometric review of global BIM research: analysis and visualization," Automation in Construction, vol. 80, pp. 37-47, 2017.

[44] D. Vasmant, "Les pôles de compétitivité biomédicaux français: une opportunité pour la recherche partenariale public-privé en santé," Bulletin de l'Académie Nationale de Médecine, vol. 193, no. 9, pp. 2035-2044, 2009.

[45] J. Whyte and S. Lobo, "Coordination and control in projectbased work: digital objects and infrastructures for delivery," Construction Management and Economics, vol. 28, no. 6, pp. 557-567, 2010.

[46] R. Jin, S. Gao, A. Cheshmehzangi, and E. Aboagye-Nimo, "A holistic review of off-site construction literature published between 2008 and 2018," Journal of Cleaner Production, vol. 202, pp. 1202-1219, 2018.

[47] H.-N. Su and P.-C. Lee, "Mapping knowledge structure by keyword co-occurrence: a first look at journal papers in technology foresight," Scientometrics, vol. 85, no. 1, pp. 6579, 2010.

[48] N. J. van Eck and L. Waltman, "Visualizing bibliometric networks," in Measuring Scholarly Impact, Y. Ding, R. Rousseau, and D. Wolfram, Eds., pp. 285-320, Springer, Cham, Switerzland, 2014.

[49] Y. Ke, S. Wang, A. P. C. Chan, and P. T. I. Lam, "Preferred risk allocation in China's public-private partnership (PPP) projects," International Journal of Project Management, vol. 28, no. 5, pp. 482-492, 2010.

[50] A. P. C. Chan, P. T. I. Lam, D. W. M. Chan, E. Cheung, and Y. Ke, "Critical success factors for PPPs in infrastructure developments: Chinese perspective," Journal of Construction Engineering and Management, vol. 136, no. 5, pp. 484-494, 2010.

[51] J. Yuan, A. Y. Zeng, M. J. Skibniewski, and Q. Li, "Selection of performance objectives and key performance indicators in public-private partnership projects to achieve value for money," Construction Management and Economics, vol. 27, no. 3, pp. 253-270, 2009.

[52] Y. Xu, J. F. Y. Yeung, A. P. C. Chan, D. W. M. Chan, S. Q. Wang, and Y. Ke, "Developing a risk assessment model for PPP projects in China-a fuzzy synthetic evaluation approach," Automation in Construction, vol. 19, no. 7, pp. 929-943, 2010.

[53] X. H. Jin and H. Doloi, "Interpreting risk allocation mechanism in public-private partnership projects: an empirical study in a transaction cost economics perspective," Construction Management and Economics, vol. 26, no. 7, pp. 707-721, 2008.

[54] C. Jacobson and S. Ok Choi, "Success factors: public works and public-private partnerships," International Journal of Public Sector Management, vol. 21, no. 6, pp. 637-657, 2008.

[55] A. Roumboutsos and K. P. Anagnostopoulos, "Public-private partnership projects in Greece: risk ranking and preferred risk allocation," Construction Management and Economics, vol. 26, no. 7, pp. 751-763, 2008.

[56] Y. Xu, A. P. C. Chan, and J. F. Y. Yeung, "Developing a fuzzy risk allocation model for PPP projects in China," Journal of Construction Engineering and Management, vol. 136, no. 8, pp. 894-903, 2010.

[57] K. C. Iyer and M. Sagheer, "Hierarchical structuring of PPP risks using interpretative structural modeling," Journal of Construction Engineering and Management, vol. 136, no. 2, pp. 151-159, 2010. 
[58] X.-H. Jin and G. Zhang, "Modelling optimal risk allocation in PPP projects using artificial neural networks," International Journal of Project Management, vol. 29, no. 5, pp. 591-603, 2011.

[59] B.-G. Hwang, X. Zhao, and M. J. S. Gay, "Public private partnership projects in Singapore: factors, critical risks and preferred risk allocation from the perspective of contractors," International Journal of Project Management, vol. 31, no. 3, pp. 424-433, 2013.

[60] P. Raisbeck, C. Duffield, and M. Xu, "Comparative performance of PPPs and traditional procurement in Australia," Construction Management and Economics, vol. 28, no. 4, pp. 345-359, 2010.

[61] R. Osei-Kyei and A. P. C. Chan, "Risk assessment in publicprivate partnership infrastructure projects," Construction Innovation, vol. 17, no. 2, pp. 204-223, 2017.

[62] S. Brthen and J. Odeck, "Road funding in Norway: experiences and perspectives," International Journal of Sustainable Transportation, vol. 3, no. 5-6, pp. 373-388, 2009.

[63] M. Sohail and O. Maslyukivska, "Learning from water sector reforms in Europe and Asia," Proceedings of the Institution of Civil Engineers-Management, Procurement and Law, vol. 162, no. 3, pp. 107-116, 2009.

[64] S. Tang and H. K. Lo, "Assessment of public private partnership models for mass rail transit-an influence diagram approach," Public Transport, vol. 2, no. 1-2, pp. 111-134, 2010.

[65] A. Mahalingam, G. A. Devkar, and S. N. Kalidindi, "A comparative analysis of public- private partnership (PPP) coordination agencies in India," Public Works Management \& Policy, vol. 16, no. 4, pp. 341-372, 2011.

[66] O. H. Petersen, "Multi-level governance of public-private partnerships, an analysis of the Irish case," HalduskultuurAdministrative Culture, vol. 12, no. 2, pp. 162-188, 2011.

[67] P. Deshpande and S. Rokade, "Prioritization and assessment of critical risks of public private partnership highway projects in India using analytical hierarchical process," International Journal of Civil Engineering and Technology, vol. 8, no. 6, pp. 605-620, 2017.

[68] R. K. Yin, Case Study Research: Design and Methods, Sage, Los Angeles, CA, USA, 5th edition, 2014.

[69] J. Kivilä, M. Martinsuo, and L. Vuorinen, "Sustainable project management through project control in infrastructure projects," International Journal of Project Management, vol. 35, no. 6, pp. 1167-1183, 2017.

[70] N. Carbonara and R. Pellegrino, "Public-private partnerships for energy efficiency projects: a win-win model to choose the energy performance contracting structure," Journal of Cleaner Production, vol. 170, pp. 1064-1075, 2018.

[71] A. Roumboutsos, A. Suárez Alemán, and R. Ågren, "Construction firms in public-private partnerships: a place to grow," Construction Management and Economics, vol. 35, no. 10, pp. 627-640, 2017.

[72] A. Shrestha, A. A. Aibinu, T. K. Chan, and C. Chen, "Risk allocation in public private partnerships in China's water projects: a principal agent approach," in Water Resources Management VII, vol. 171, pp. 85-96, WIT Press, Southampton, UK, 2013.

[73] S. Zhang, A. P. C. Chan, Y. Feng, H. Duan, and Y. Ke, "Critical review on PPP research-a search from the Chinese and international journals," International Journal of Project Management, vol. 34, no. 4, pp. 597-612, 2016.

[74] T. Yang, R. Long, and W. Li, "Suggestion on tax policy for promoting the PPP projects of charging infrastructure in
China," Journal of Cleaner Production, vol. 174, pp. 133-138, 2018.

[75] M. R. Guarini and F. Battisti, "A model to assess the feasibility of public-private partnership for social housing," Buildings, vol. 7, no. 2, p. 44, 2017.

[76] M. Opara and F. Elloumi, "The emergence of public-private partnerships (P3s) in Alberta: lessons from the Anthony Henday highway," Canadian Public Administration, vol. 60, no. 2, pp. 268-288, 2017.

[77] A. Shrestha, T. K. Chan, A. A. Aibinu, C. Chen, and I. Martek, "Risks in PPP water projects in China: perspective of local governments," Journal of Construction Engineering and Management, vol. 143, no. 7, Article ID 05017006, 2017.

[78] X. Y. Cai and G. G. Zhou, "The real option value analysis of income adjustment during operating period in the toll road public private partnership projects," Journal of Transportation Systems Engineering and Information Technology, vol. 17, no. 3, pp. 7-11, 2017.

[79] K. Curtain and J. Betts, "Busting some of the public private partnership myths from a government perspective," Australian Journal of Public Administration, vol. 76, no. 3, pp. 283-287, 2017.

[80] D. Danau and A. Vinella, "From fixed to state-dependent duration in public-private partnerships," Journal of Economics \& Management Strategy, vol. 26, no. 3, pp. 636-660, 2017.

[81] Z. Chen, N. Daito, and J. L. Gifford, "Socioeconomic impacts of transportation public-private partnerships: a dynamic CGE assessment," Transport Policy, vol. 58, pp. 80-87, 2017.

[82] M. Regan, J. Smith, and P. E. D. Love, "Financing of public private partnerships: transactional evidence from Australian toll roads," Case Studies on Transport Policy, vol. 5, no. 2, pp. 267-278, 2017.

[83] S. K. Enloe, L. A. Schulte, and J. C. Tyndall, "Public-private partnerships working beyond scale challenges toward water quality improvements from private lands," Environmental Management, vol. 60, no. 4, pp. 574-587, 2017.

[84] M. Himmel and M. Siemiatycki, "Infrastructure publicprivate partnerships as drivers of innovation? Lessons from Ontario, Canada," Environment and Planning C: Politics and Space, vol. 35, no. 5, pp. 746-764, 2017.

[85] B. Guo, W. Yang, and H. Zhang, "Government compensation on rental indemnificatory housing in public private partnerships," Boletin Tecnico/Technical Bulletin, vol. 55, no. 9, pp. 476-485, 2017.

[86] Z. Muhammad and F. Johar, "A conceptual framework for evaluating the success of public-private partnership (PPP) projects," Advanced Science Letters, vol. 23, no. 9, pp. 9130-9134, 2017.

[87] E. I. Antillon, K. R. Molenaar, and A. Javernick-Will, "Evaluating the effect of contract timing on lifecycle-design innovation in public-private partnerships: comparative case study of highway projects," Journal of Construction Engineering and Management, vol. 143, no. 4, Article ID 05016023, 2017.

[88] H. Ç. Demirel, W. Leendertse, L. Volker, and M. Hertogh, "Flexibility in PPP contracts-dealing with potential change in the pre-contract phase of a construction project," Construction Management and Economics, vol. 35, no. 4, pp. 196-206, 2017.

[89] N. Agarchand and B. Laishram, "Sustainable infrastructure development challenges through PPP procurement process," International Journal of Managing Projects in Business, vol. 10, no. 3, pp. 642-662, 2017. 
[90] E. Reeves and D. Palcic, "Getting back on track: the expanded use of PPPs in Ireland since the global financial crisis," Policy Studies, vol. 38, no. 4, pp. 339-355, 2017.

[91] B. Rakic, T. Milenkovic-Kerkovic, and T. Radjenovic, "Infrastructure development through public-private partnership," Actual Problems of Economics, vol. 152, no. 2, pp. 94-105, 2014.

[92] C. Mukhopadhyay, "A nested framework for transparency in public private partnerships: case studies in highway development projects in India," Progress in Planning, vol. 107, pp. 1-36, 2016.

[93] J. Cao and M. Yang, "The dynamic allocation strategy of profits from PPP projects," Agro Food Industry Hi-Tech, vol. 28, no. 1, pp. 3362-3365, 2017.

[94] S. S. Cutrim, J. A. M. Tristão, and V. T. V. Tristão, “Application of the Delphi method to identify and evaluate the factors restricting the realization of public-private partnerships (PPP)," Revista Espacios, vol. 38, no. 22, p. 29, 2017.

[95] E. Dmitrieva and M. Guseva, "Justification of approach to classification of innovations in public-private partnership," Economic Annals-XXI, vol. 163, no. 1-2, pp. 64-70, 2017.

[96] T. Tkacheva and L. Afanasjeva, "Public-private partnership as an encouragement tool of innovative development," Istrazivanja I Projektovanja Za Privredu, vol. 15, no. 3, pp. 242-246, 2017.

[97] M. H. Sobhiyah, M. R. Bemanian, and Y. K. Kashtiban, "Increasing VFM in PPP power station projects-case study: rudeshur gas turbine power station," International Journal of Project Management, vol. 27, no. 5, pp. 512-521, 2009.

[98] D. Juričić and S. Marenjak, "Value for money evidence in croatian PPP projects," Ekonomski Pregled, vol. 67, no. 6, pp. 581-604, 2016.

[99] P. T. Nguyen and V. Likhitruangsilp, "Identification risk factors affecting concession period length for public-private partnership infrastructure projects," International Journal of Civil Engineering and Technology, vol. 8, no. 6, pp. 342-348, 2017.

[100] S. K. Sundararajan and C. L. Tseng, "Managing project performance risks under uncertainty, using a dynamic capital structure approach in infrastructure project financing," Journal of Construction Engineering and Management, vol. 143, no. 8, article 04017046, 2017.

[101] X. Wu, R. Schuyler House, and R. Peri, "Public-private partnerships (PPPs) in water and sanitation in India: lessons from China," Water Policy, vol. 18, no. 1, pp. 153-176, 2016.

[102] G. Aerts, M. Dooms, and E. Haezendonck, "Knowledge transfers and project-based learning in large scale infrastructure development projects: an exploratory and comparative ex-post analysis," International Journal of Project Management, vol. 35, no. 3, pp. 224-240, 2017.

[103] S. Kyvelou, N. Marava, and G. Kokkoni, "Perspectives of local public-private partnerships towards urban sustainability in Greece," International Journal of Sustainable Development, vol. 14, no. 1-2, pp. 95-111, 2011.

[104] G. U. Atmo, C. Duffield, L. Zhang, and D. I. Wilson, "Comparative performance of PPPs and traditional procurement projects in Indonesia," International Journal of Public Sector Management, vol. 30, no. 2, pp. 118-136, 2017.

[105] S. V. Khusainova, F. A. Ruslanovna, and K. S. Damirovna, "Public-private partnership as the basis of interaction between the state and business," International Business Management, vol. 9, no. 5, pp. 909-916, 2015.

[106] L. V. Semenova, N. A. Zaitseva, A. A. Larionova, A. A. Gorbacheva, and E. V. Ivanova, "International experience of implementation projects of public-private partnership in tourism," Man in India, vol. 97, no. 14, pp. 317-327, 2017.

[107] K. Feng, W. Xiong, S. Wang, C. Wu, and Y. Xue, "Optimizing an equity capital structure model for public-private partnership projects involved with public funds," Journal of Construction Engineering and Management, vol. 143, no. 9, Article ID 04017067, 2017.

[108] L. Ma, Y. Le, H. Li, R. Jin, P. Piroozfar, and M. Liu, "Regional comparisons of contemporary construction industry sustainable concepts in the Chinese context," Sustainability, vol. 10, no. 11, p. 3831, 2018.

[109] P. E. D. Love, J. Liu, J. Matthews, C.-P. Sing, and J. Smith, "Future proofing PPPs: life-cycle performance measurement and building information modelling," Automation in Construction, vol. 56, pp. 26-35, 2015.

[110] G. Ren and H. Li, "BIM based value for money assessment in public-rivate partnership" in Proceedings of the 18th IFIPWG 5.5 Working Conference on Virtual Enterprises, PRO-VE 2017, H. Afsarmanesh, L. M. Camarinha-atos, and R. Fornasiero, Eds., vol. 56, pp. 51-62, Springer New York LLC, Vicenza, Italy, September 2017.

[111] R. Osei-Kyei and A. P. C. Chan, "Developing a project success index for public-private partnership projects in developing countries," Journal of Infrastructure Systems, vol. 23, no. 4, Article ID 04017028, 2017. 


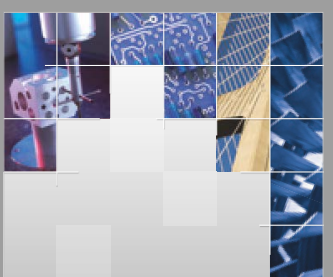

\section{Enfincering}
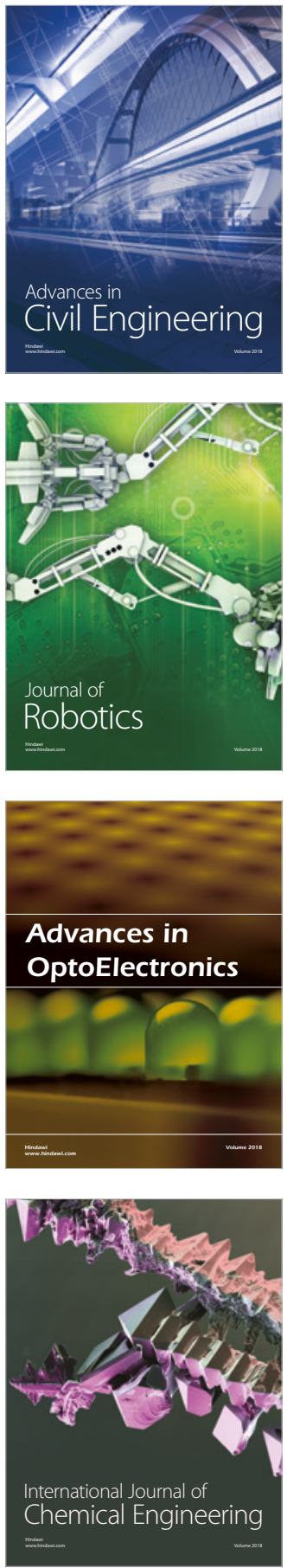

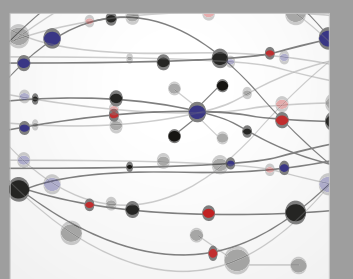

\section{Rotating \\ Machinery}

The Scientific World Journal

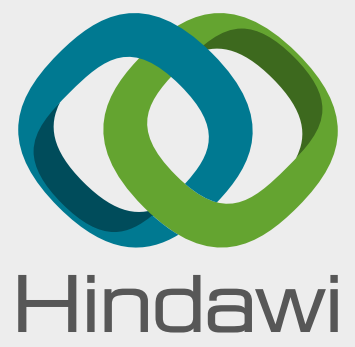

Submit your manuscripts at

www.hindawi.com
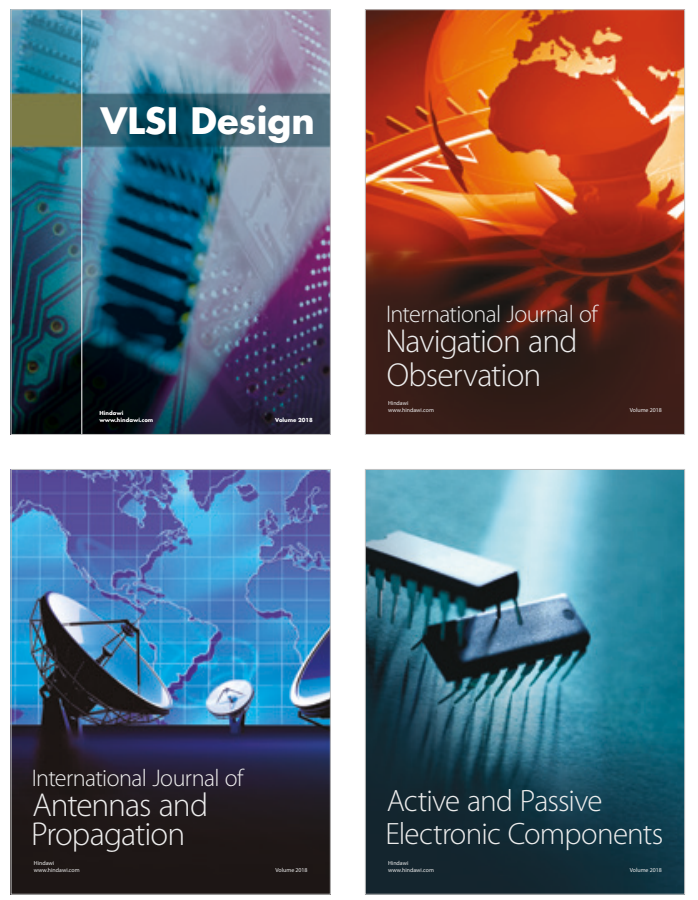
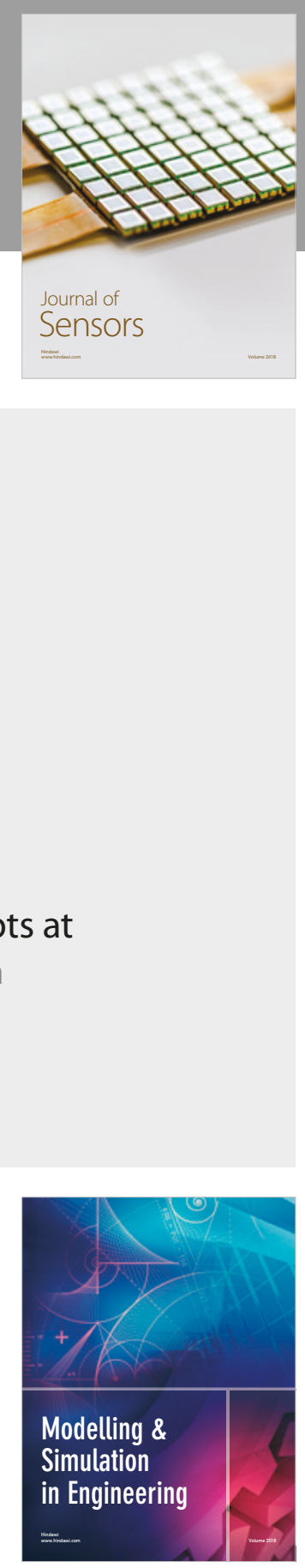

\section{Advances \\ Multimedia}
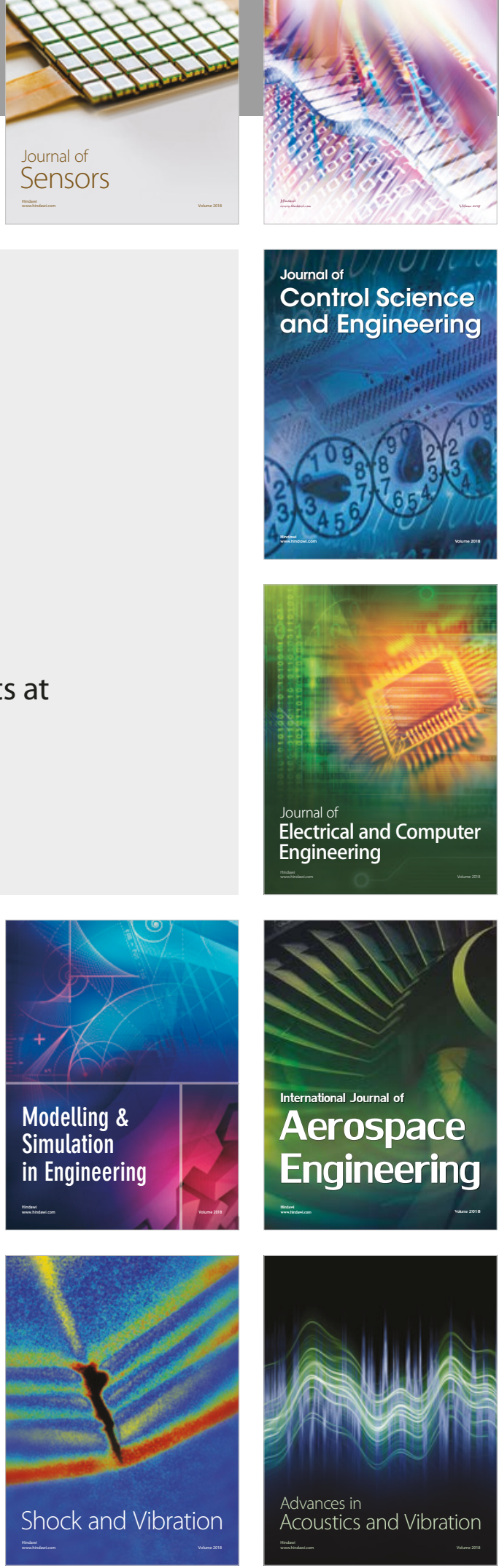